GEOLOGIJA 33, 315-351 (1990), Ljubljana

https://doi.org/10.5474/geologija.1990.008

UDK 551.762:550.4(497.12) $=20$

\title{
Stratigraphy and geochemistry of Jurassic carbonate rocks from Suha krajina and Mala gora mountain (Southern Slovenia)
}

\author{
Christian Strohmenger \\ BEB Erdgas und Erdöl GmbH \\ Riethorst 12, D-3000 Hannover 51 \\ Stevo Dozet \\ Geološki zavod Ljubljana, Dimičeva 14, 61000 Ljubljana
}

\begin{abstract}
Detailed sedimentological investigations have been carried out in the section Kompolje-Ogorelec at the Mala gora mountain, and in the section Krka-Mali Korinj at Suha krajina about $35 \mathrm{~km}$ SSE from Ljubljana (NW Yugoslavia). In both sections a complete sequence of the Jurassic calcareous beds is exposed, including the contacts between the Upper Triassic and the Lower Lias, and the Upper Malm and the Lower Cretaceous. The field studies showed that at least the uppermost part of Dogger was not deposited. The thickness of the Jurassic sequence is about $1500 \mathrm{~m}$. The stratigraphic relationships have been established by means of micro - and macrofossils, and by lithologic comparisions. The interpretation of microfacies has been supplemented by geochemical, micropaleontological and some other analyses. A polymict karst breccia within the Lower Malm beds proves a long lasting emergence of the carbonate platform during the Upper Malm; it is apparently the equivalent of the bauxite horizon commonly developed between the Lower and the Upper Malm in Slovenia. The distribution of trace elements follows the trends implied by the microfacies analyses.
\end{abstract}

\section{Introduction}

Jurassic carbonate deposits exposed SSE of Ljubljana consist of well developed sequences of shallow subtidal, intertidal and supratidal facies. These carbonates were studied at two different localities named section 1 and section 2 (Fig. 1). The two sections are documented by about 800 samples. By means of aceton peels (all samples), thin sections (selected samples), X-ray diffraction (all samples), scanning electron microscopy and geochemical analyses (carbonate content and atomic absorption; all samples) the microfacies, diagenesis, geochemistry and the stratigraphy of the carbonates were investigated.

The stratigraphic and tectonic evolution of the two sections is the main subject of the present paper.

The appendix (section 1, section 2) gives a compilation of these studies together with the results of the geochemical analyses. 


\section{Section 1}

Section 1 is situated in the Mala gora mountain about 35 kilometers SSE of Ljubljana (Fig. 1). A series of carbonate rocks (Middle Lias to Upper Malm) is well exposed directly at the path which starts near the village of Kompolje and leads up to a site called Ogorelec (about $950 \mathrm{~m}$ ).

Due to the strong tectonic overprint it is very difficult to determine the stratigraphy of these carbonates.

Micropaleontological investigations and field observations helped to identify two evident faults and two presumed ones within beds of the Lower Malm (Fig. 2, Appendix: section 1, c-d, g). In addition, one fault separates the stromatolitic carbonates of the Upper Malm from Lower Malm (Dogger?) carbonates with intercalated ooid grainstones (Fig. 2, Appendix: section 1, f). The latter were thought to be of Upper Malm age by Strohmenger et al. $(1987$, b) but it is now clear (B u s er, 1987 pers. com.) that they are upthrusted carbonate rocks of the Lower Malm (Fig. 3). Beside these obvious repetitions of Lower Malm strata, also the contact of the Lower Malm and the Upper Malm appears to be slightly tectonically overprinted (Fig. 2, Appendix: section 1, e).

It is possible that section 1 contains some more minor faults which could not be identified due to the locally insufficient outcrops.

These tectonical faults never represent overthrusts. They are on the contrary clearly upthrow faults of which the net slip has an upward directed vertical component.

Thicknesses of the Jurassic carbonate rocks are only of approximate values. Due to the outcrop conditions the real thickness of the section can easily differ by some tens of meters from the estimated value of about $1390 \mathrm{~m}$.

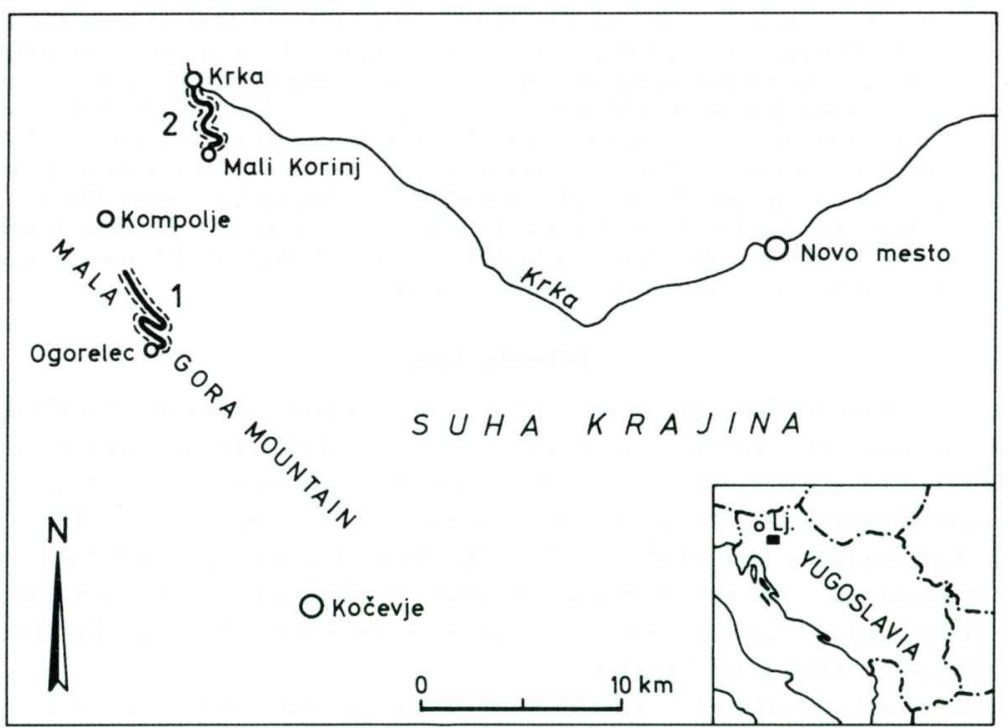

Fig. 1. Location map of the investigated areas, section 1 and section 2; Lj.: Ljubljana 


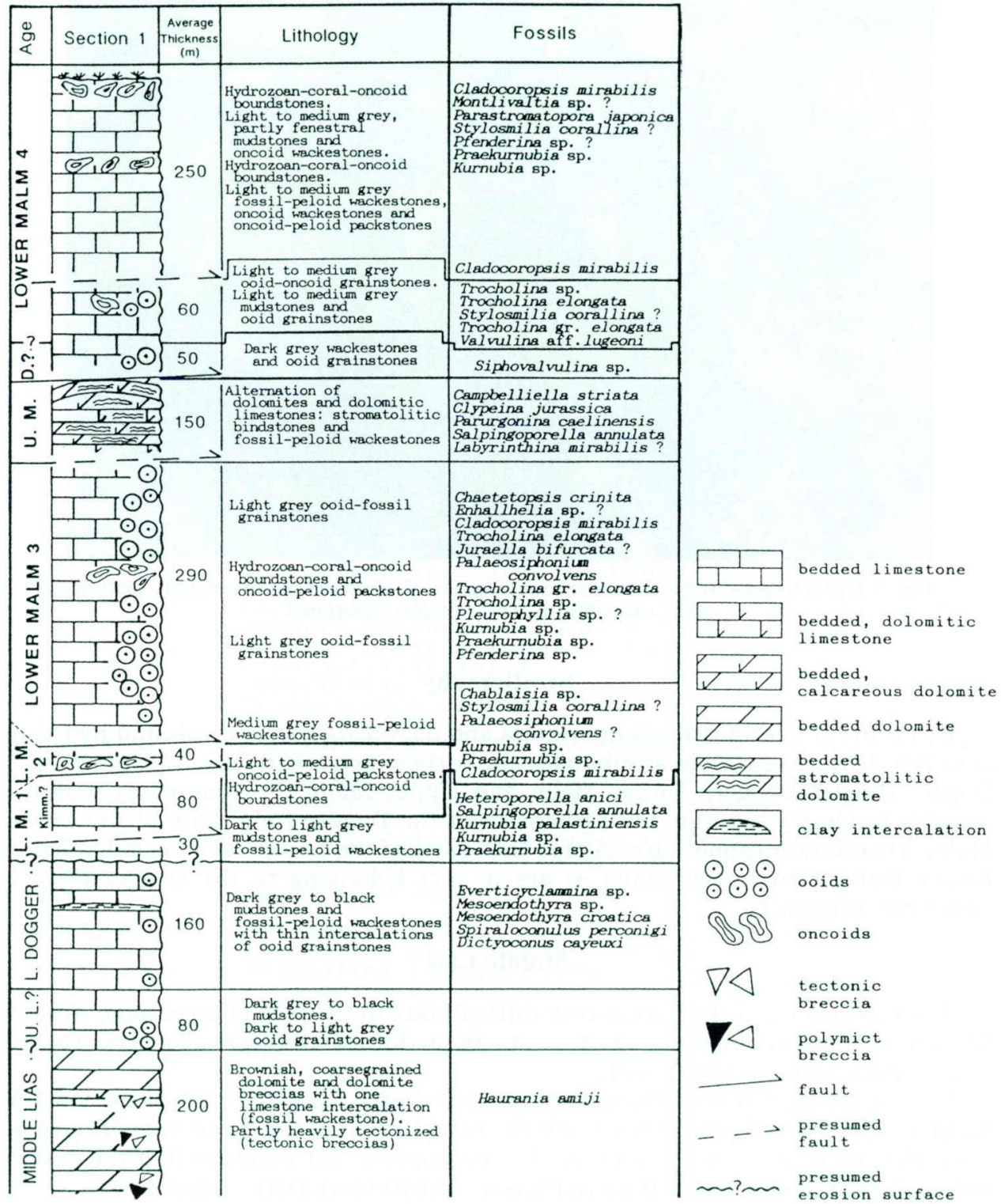

Fig. 2. Schematic column of the Jurassic carbonate rocks from Kompolje, section 1 U. L. Upper Lias; L. M. Lower Malm; Kimm Kimmeridgian; U. M. Upper Malm; D. Dogger 


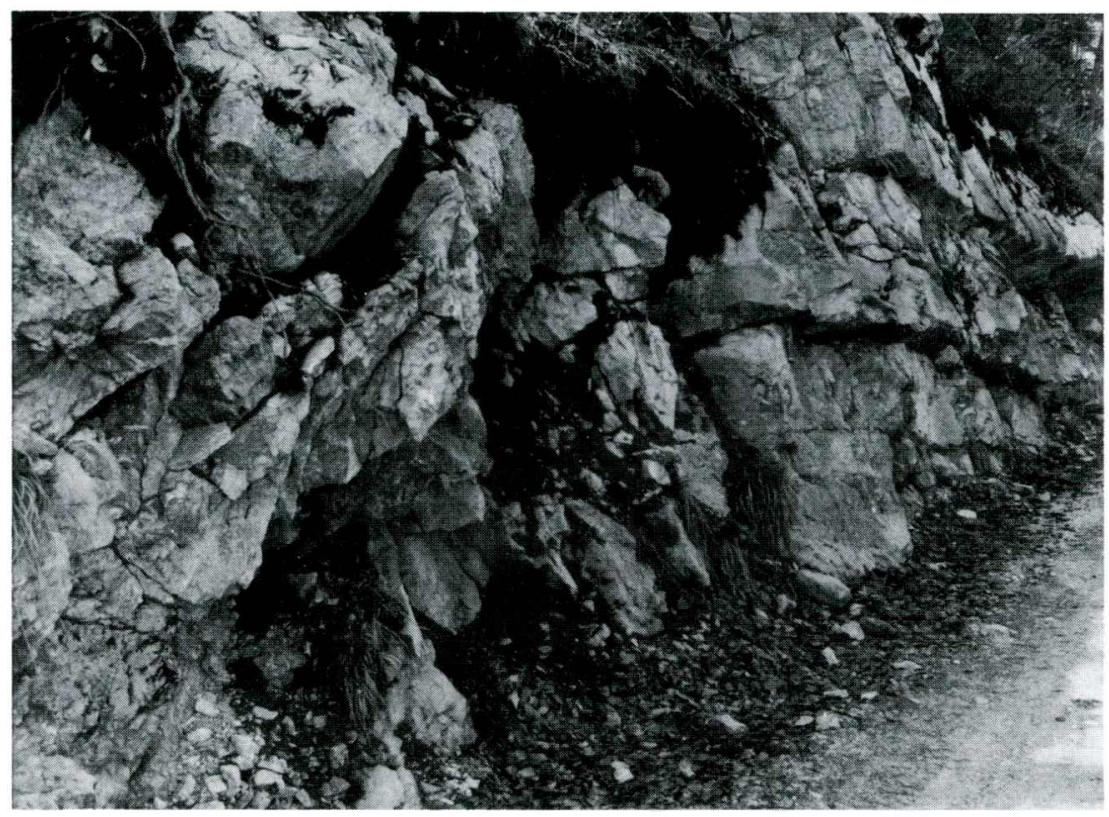

Fig. 3. Upthrusted Lower Malm carbonate beds (left) juxtaposed to strongly tectonized Lower Malm strata (right). Section 1

\section{Stratigraphy}

By means of microfossils (foraminifera and dasycladaceans), corals and hydrozoans (Tab. 1) it was possible to subdivide the carbonates in Middle Lias, Upper Lias?, Dogger (Lower Dogger), Lower Malm and Upper Malm. In some cases it is not possible to clearly separate the carbonates of the Dogger from those of the Lower Malm. Therefore it cannot be excluded that parts of the Lower Malm (subdivided in Lower Malm 1 to Lower Malm 4) are in fact belonging to the Dogger (Fig. 2, Appendix: section 1).

\section{Middle Lias}

The subdivision of the Lias is very difficult due to the lack of good index fossils. The subdivision presented here is done chiefly by lithostratigraphical considerations (Fig. 2, Appendix: section 1, a-d).

Buser (1974) describes the underlying and mostly dolomitic beds of section 1 as Middle Lias. The only index fossil which could be found, the foraminifer Haurania amiji Henson is not suitable to prove this assumption, but indicates that the described carbonates are younger than Hettangian (S e p tf on tain e, 1988).

\section{Upper Lias?}

The stratigraphic boundary between the Middle and Upper Lias is very arbitrary (Fig. 2, Appendix: section 1, b). Unlike the ooid grainstones of the Middle Lais of 
Table 1. Index fossils of section 1

Age

Index Fossils

Middle Lias

Upper Lias

Lower Dogger

Lower Malm 1

Lower Malm 2

Lower Malm 3

Upper Malm

Dogger?

Lower Malm 4
Haurania amiji Henson

Dictyoconus cayeuxi Lukas

Spiraloconulus perconigi Allemann \& Schroeder Everticyclammina sp.

Mesoendothyra sp.

Mesoendothyra croatica Gusić

Praekurnubia sp.

Kurnubia sp.

Kurnubia palastiniensis Henson

Heteroporella anici Nikler \& Sokac

Salpingoporella annulata Carozzi

Praekurnubia sp.

Kurnubia sp.

Chablaisia sp.

Palaeosiphonium convolvens (Praturlon) Elliott?

Cladocoropsis mirabilis Felix

Stylosmilia corallina Koby?

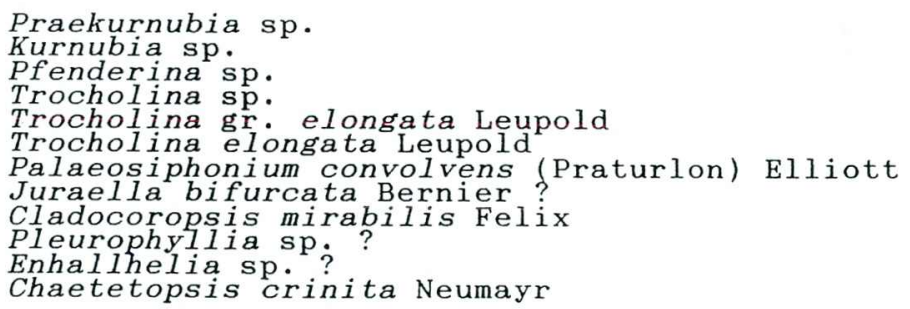

Labyrinthina mirabilis Weynschenk?

Salpingoporella annulata Carozzi

Clypeina jurassica Favre

Parurgonina caelinensis Cuvillier

Aberrant Tintinnids:

Campbelliella striata (Carozzi) Bernier

Siphovalvulina sp.

Trocholina sp.

Trocholina gr. elongata Leupold

Trocholina elongata Leupold

Pfenderina sp.

Praekurnubia sp.

Kurnubia sp.j.

Cladocoropsis mirabilis Felix

Montlivaltia sp. ?

Stylosmilia coralitina Koby?

Parastromatopora japonica Yabe \& Sugiyama

section 2 which are extremely rich in microfossils (index fossils), the ooid grainstones which overlay the dolomites of the Middle Lias (section 1) show nearly no biological components. The ooid grainstones are followed by dark mudstones which pass into dark wackestones/mudstones of undoubtedly Lower Dogger strata. until new data are available, the oolitic beds and the overlying mudstones (which are also devoid of index fossils) are attributed to the Upper Lias. 


\section{Lower Dogger}

The microfossils of the Dogger below the first presumed fault (Fig. 1, Appendix: section 1, b-c) such as Mesoendothyra croatica Gušić, Spiraloconulus perconigi Allemann \& Schroeder Dictyoconus cayeuxi Lukas (synonym to Gutnicella cayeuxi (Lukas) Gutnic \& Moullade; Moulla de et al., 1981), all indicate to Lower Dogger age or respectively to beds older than Callovian. The only indication of Upper Dogger strata besides the foraminifer Praekurnubia sp. could give the alga Palaeosiphonium convolvens (Praturlon) Elliott (see below).

\section{Lower Malm}

The carbonate rocks of the Lower Malm are strongly tectonized and can be subdivided into four units (Lower Malm 1 to Lower Malm 4). They often contain an obviously big quantity of foraminifera which, by use of the criteria stated by Redmond (1964), must be ascribed to Praekurnubia sp. (Septfontaine, 1989 pers, com.). The absence of Kurnubia sp. makes Dogger age for large parts of these carbonates very probable (see below).

\section{Lower Malm 1}

The carbonate rocks directly overlaying the beds of the Lower Dogger up to the first evident fault are described as Lower Malm 1 (Fig. 2, Appendix: section 1, c-d). The dominant fossil, however, is the foraminifer Praekurnubia sp. (Septfontaine, 1989 pers. com.) which is supposed to be of Dogger age, and not Kurnubia palastiniensis Henson (Radoičić, 1987 pers. com.) which is an index fossil of the Upper Jurassic (Kimmeridgian). On the contrary, good indications of Lower Malm strata are given by the alga Heteroporella anici Nikler \& Sokač (Pl. 2, Fig. 1) and Salpingoporella annulata Carozzi. The fossil assemblage of Heteroporella anici Nikler \& Sokač, Salpingoporella annulata Carozzi, Kurnubia palastiniensis Henson and/or Praekurnubia sp. seems very unusual. Keeping in mind the facies dependence of benthic foraminifera, it may be suggested that the phylogenetic development of the species Praekurnubia/Kurnubia is highly diachronous, which means that the species Praekurnubia in fact can be more frequent in Lower Malm carbonates than presumed.

The occurrence of Heteroporella anici Nikler \& Sokač and Salpingoporella annulata Carozzi as well as the microfacies development of these carbonates are supporting the assumption that they are of Lower Malm age (probably Kimmeridgian: Radoiči ć, 1987 pers. com.).

\section{Lower Malm 2}

The carbonate rocks between the first and second evident faults (Fig. 2, Appendix: section 1, d) are described as Lower Malm 2, despite the presence of Praekurnubia sp., Chablaisia sp. and very probably Palaeosiphonium convolvens (Praturlon) Elliott (R a d o i č i ć, 1987 pers. com.). Other fossils such as Kurnubia sp., Cladocoropsis mirabilis Felix (abundant) and Stylosmilia carollina Koby? as well as the facies (hydrozoan-coral-oncoid boundstones) clearly indicate the Lower Malm age of the unit. 


\section{Lower Malm 3}

The carbonate rocks of the Lower Malm 3 are juxtaposed to the previously described ones (Fig. 1, Appendix: section 1, d-e). The lowermost micritic carbonates of this sequence again are rich in the foraminifer Praekurnubia sp. and pass into a thick succession of ooid grainstones (about $260 \mathrm{~m}$ ) which is interrupted only by an intercalation of hydrozoan-coral-oncoid boundstones. Within the lower part of the ooid grainstones (about $100 \mathrm{~m}$ ) the alga Palaeosiphonium convolvens (Praturlon) Elliott could be identified. Elli ot t $(1977,1985)$ describes this alga as typical in the Upper Dogger beds (Upper Bathonian to lowermost Callovian) within the realm of the Tethys and (rarely) in extra-Tethyan deposits. R a d o i čić (1966) on the contrary mentioned as range for Pseudocodium convolvens Praturlon (renamed by Elliott, 1985 as Palaeosiphonium convolvens (Praturlon Elliott) the uppermost Upper Dogger to the lower parts of the Lower Malm. On my inquiries Mrs. Radoičić and Mr. Elliott unfortunately could not give any new information concerning the age of this alga (R a doičić, 1987 pers. com., Elli ott, 1989 pers. com.).

It is therefore possible that the lower part of the relatively thick sequence (about $186 \mathrm{~m}$ ) belongs to the Upper Dogger. Against this interpretation, however, argue the following reasons:

- Section 2 (Fig. 4, Appendix: section 2, e) shows an undisturbed transition of definitely Lower Dogger (older than Callovian?) to Lower Malm strata (the uppermost carbonate rocks of the Dogger contain the foraminifera Mesoendothyra croatica Gušić and Dictyoconus cayeuxi Lukas).

- Mudstones/wackestones of Lower Malm age are always intercalated between the ooid grainstones of the Dogger and the ooid grainstones of the Lower Malm (section 2; section 1: beneath and above the first presumed fault, above the second evident fault). Those intercalations of Lower Malm mudstones/wackestones directly above the Dogger/Malm boundary are typical of the Jurassic beds of Slovenia (Buser, 1987 pers. com.). On the other hand, the ooid grainstones containing the alga Palaeosiphonium convolvens (Praturlon) Elliott are placed above such an intercalation and pass without interruption into assured Lower Malm ooid grainstones. No mudstones or wackestones are intercalated at this site.

- Bosellini et al. (1981) state a short drop of sea level during the Callovian which has exposed large parts of the Friuli Platform and interrupted the formation of ooids.

- Halla m $(1978,1988)$ assumes most important sea level falls in the Late Callovian and in the end of the Bathonian.

Accordingly, the entire sequence of ooid grainstones, including those containing the alga Palaeosiphonium convolvens (Praturlon) Elliott, are thought to be of Lower Malm age.

\section{Upper Malm}

The contact between the beds of the Lower Malm and the Upper Malm also seems to be slightly tectonically overprinted. The occurrence of the index fossil Clypeina jurassica Favre above this fault (Fig. 2, Appendix: section 1, e-f), however, undoubtedly indicates the Upper Malm age of the superposed micritic and partly strongly 
dolomitized carbonates. The dolomites as well as the calcareous dolomites of the Upper Malm often show a pronounced cryptalgal lamination. Within the intercalated bedded limestones and dolomitized limestones, abundant Salpingoporella annulata Carozzi and aberrant Tintinnids (synonym to Campbelliella striata Carozzi; (B e r nier, 1974) can be found beside Clypeina jurassica Favre (Pl. 2, Fig. 3).

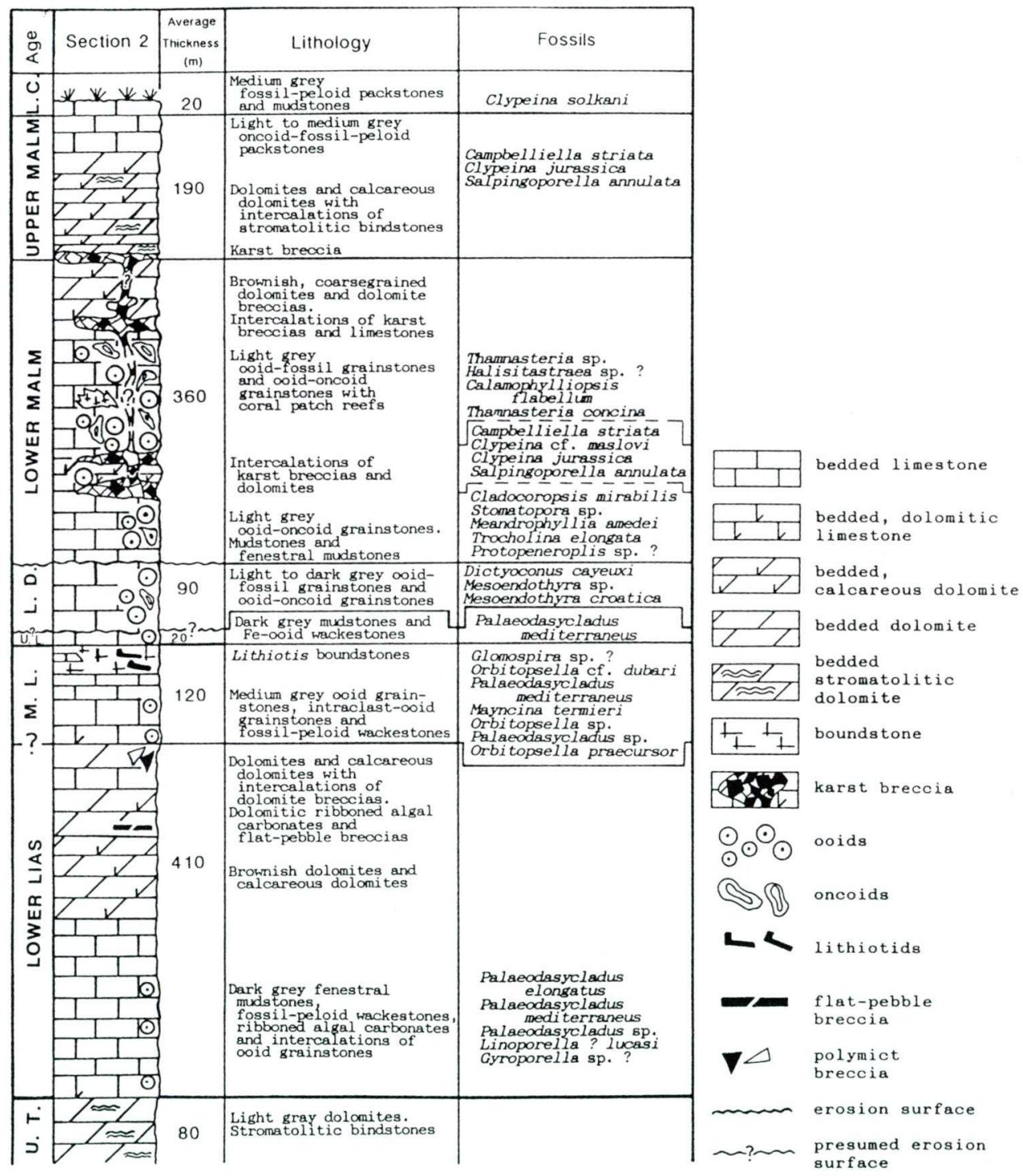

Fig. 4. Schematic column of the Jurassic carbonate rocks from Krka, section 2

U. T. Upper Triassic; M. L. Middle Lias; U. L. Upper Lias; L. D. Lower Dogger; L. C. Lower Cretaceous 


\section{Lower Malm 4 ( Dogger?)}

The Upper Malm carbonate beds are in tectonic contact (juxtaposed) with Dogger and/or Lower Malm carbonates (Dogger?/Lower Malm 4; Fig. 2, Appendix: section 1 , $\mathrm{f}-\mathrm{h})$ which contain a thick intercalation of ooid grainstones $(38,5 \mathrm{~m})$. The abundance of corals and hydrozoans within these oolites and in the superimposed beds (abundant Cladocoropsis mirabilis Felix) clearly indicates the Lower Malm age of the oolitic beds and the following micritic carbonates (Fig. 2, Appendix: section 1, g-h).

In the lowermost beds of the upthrusted carbonates (about $55 \mathrm{~m}$ ) no index fossils could be identified. This means that the stratigraphical position of these carbonates is not defined. The microfacies development of the sequence, composed mostly of micritic carbonates with thin oolithic intercalations, shows much similarities with the carbonates (and microfacies types) of the Lower Dogger (Stroh m en g e r, 1988). It is therefore possible that also some parts of the Dogger (Lower Dogger?) are upthrusted and juxtaposed to the Upper Malm carbonate rocks (Fig. 2, Appendix: section $1, \mathrm{f}$-g).

A third presumed fault probably separates the upthrown oolites of the Lower Malm from micritic carbonates of the same age (Fig. 2, Appendix: section 1, g) which are rich in oncoids (oncoid boundstones), corals and hydrozoans (Cladocoropsis mirabilis Felix).

\section{Lithology}

Limestones are the predominant carbonates of section 1. Dolomites occur only in the Middle Lias and Upper Malm. Except of one very tectonized limestone intercalation (about $10 \mathrm{~m}$, lower part brecciated), the entire Middle Lias consists of dolomites which are mostly brecciated.

The Upper Malm is built up by an alternation of limestones and (mostly) dolomites. The dolomites commonly show marked cryptalgal laminations.

Non-carbonate sediments are only present in the form of a $10 \mathrm{~cm}$ thick clay lens which probably represents rather a diagenetically induced layer than a sediment (Strohmenger, 1988).

The thicknesses of the beds vary between less than $10 \mathrm{~cm}$ (platy stromatolitic dolomites, Upper Malm) and more than $1 \mathrm{~m}$. The average thickness of the carbonate beds is nevertheless less than $1 \mathrm{~m}$.

\section{Section 2}

Section 2 is located near Krka, about $30 \mathrm{~km}$ SSE of Ljubljana (Fig. 1). An undisturbed succession of carbonate rocks (Upper Triassic to Lower Cretaceous) is exposed directly on or close to the path which leads from Krka to a hill with the small village of Mali Korinj (about $750 \mathrm{~m}$ ).

In contrast with section 1 , the carbonate beds of section 2 are tectonically undisturbed, but are in places very badly exposed. This is why the vertical transition of the beds are not always visible. The real value of the thickness may therefore deviate by some tens of meters from the estimated value of about $1270 \mathrm{~m}$. 


\section{Stratigraphy}

With the exception of the boundaries betwen the beds ob the Lower Lias to the Middle Lias and the Lower Malm to the Upper Malm the sections containing the stratigraphical boundaries are well exposed and proved by index fossils (Tab. 2) and/ or field observations.

Section 2 can be easily subdivided into Upper Triassic (Main Dolomite), Lower Lias, Middle Lias, Upper Lias, Lower Dogger, Lower Malm, Upper Malm and Lower Cretaceous (Fig. 4, Appendix: section 2).

\section{Lower Lias}

The boundary of the Upper Triassic (Main Dolomite) to the Lower Lias is very well exposed. The light gray dolomites of the Upper Triassic pass continiously into the brownish limestones of the Lower Lias (Fig. 4, Appendix: section 2, a-c) which contain the algae Palaeodasycladus mediterraneus Pia and Palaeodasycladus elongatus Praturlon (Pl. 1, Fig. 1).

Table 2. Index fossils of section 2

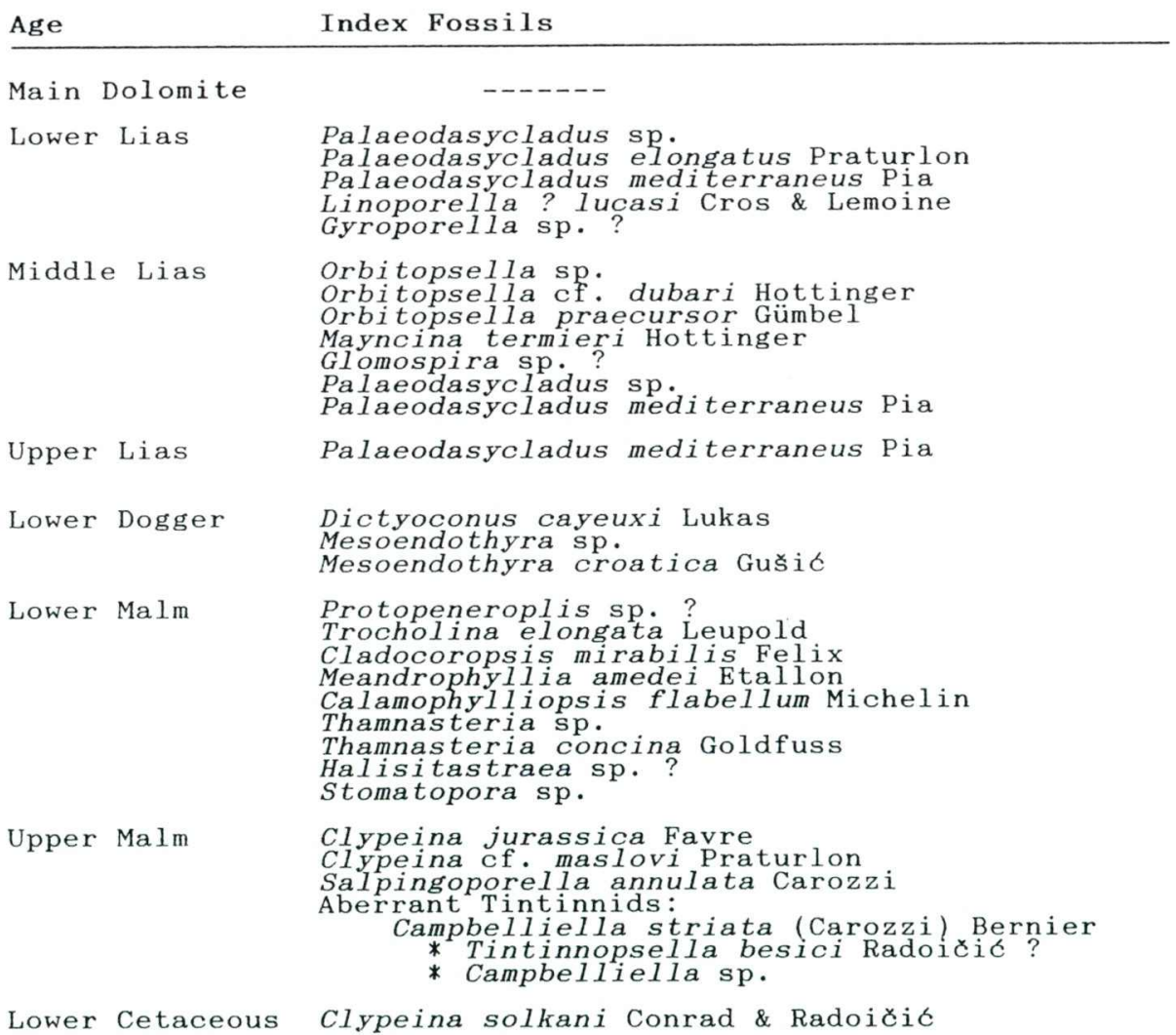




\section{Middle Lias}

The boundary between the Lower Lias and Middle Lias has been fixed with the first appearance of Orbitopsella praecursor Gümbel (Fig. 4, Appendix: section 2, c; Pl. 1, Fig. 2). Connected with this stratigraphical change is also a petrographical change from dolomites (Lower Lias) to limestones (Middle Lias) in which, beside other index fossils, also Mayncina termieri Hottinger (Pl. 1, Fig. 3) could be found. It is of course, also possible that the boundary is situated somewhat lower within the underlaying dolomites. Unfortunately, these dolomites contain no determinable fossils.

\section{Upper Lias}

The delimitation of the Upper Lias beds is solely based on field observations (Fig. 4, Appendix: section 2, d). The part of the carbonate sequence overlaying the uppermost Middle Lias with the Lithiotis-bioherms and underlaying undoubtedly Lower Dogger carbonates (oolites with the index fossils) Dictyoconus cayeuxi Lukas and Mesoendothyra croatica Gušić) is very well exposed and undisturbed. The carbonates are built up by very dark micrites which are framed by intraclast-ooidpeloid grainstones at the base (which contain Palaeodasycladus mediterraneus Pia and abundant Codiacean fragments) and iron-ooid wackestones at the top. The latter show a fossil assemblage (bentic foraminifera, ostracodes and strongly bored crinoid fragments with thick micrite envelopes) that resembles typical Upper Lias fossil assemblages (R a d o i č i ć, 1987 pers. com.) The thickness of the so-called Upper Lias carbonates varies between $12 \mathrm{~m}$ and $30 \mathrm{~m}$. This limited thickness and the ferriferous ooid deposits at the top of the Upper Lias probably can be interpreted as a stratigraphical gap between the Upper Lias and the Lower Dogger.

\section{Lower Dogger}

The Lower Dogger beds are exclusively developed as ooid grainstones which laterally can also be somewhat dolomitized (Fig. 4, Appendix: section 2, d-e). Although such thick oolitic series (about $84 \mathrm{~m}$ ) are thought to be typical of the Lower Malm, the described sequence is of undoubtedly Lower Dogger age. The uppermost beds of the ooid grainstones are rich in the foraminifer Dictyoconus cayeuxi Lukas (Pl. 1, Fig. 4). According to Septfonta ine (1988), the range of this foraminifer is from Upper Aalenien (?) to Bajocian (Bathonian ?). Dictyoconus cayeuxi Lukas together with Mesoendothyra croatica Gušić (which is also present within the ooid grainstones) are well known index fossils of the Lower Dogger in the Dinarids (R a d o i čić, 1966, Gušić, 1969). Outside Yugoslavia these foraminifera are known from the Lower to Middle Dogger.

Oman and Spain: Dictyoconus cayeuxi Lukas together with Spiraloconulus perconigi Allemann \& Schroeder: Bajocian to Bathonian (Allemann \& Schroeder, 1972, 1980)

West Thailand: Lucasella kaempferi Kemper, synonym to Dictyoconus cayeuxi Lukas: Lower to Middle Dogger (Kemper, 1976; Hagen \& Kemper, 1976; Kemper et al., 1976)

By means of the index fossils it is well documented that at least the Callovian (or the upper part of the Callovian) is not developed in the investigated area. 


\section{Lower Malm}

The Lower Malm beds mainly consist of different ooid grainstones which are partly interrupted by breccias (Fig. 4, Appendix: section 2, e-g). The breccias are of obviously polymict composition. They contain typical clasts of the Lower Malm (ooid grainstones and/or oncoid-peloid packstones) as well as wackestones whose fossil content (Clypeina jurassica Favre, Clypeina cf. maslovi Praturlon, Salpingoporella annulata Carozzi and Campbelliella striata (Carozzi) Bernier) clearly identifies them to be of Upper Malm age (Fig. 5). These breccias occur in three horizons within the Lower Malm Carbonate rocks and are certainly wedging out laterally. The breccias themselves and the adjacent limestone beds are often heavily dolomitized. The polymict composition of the breccias (clasts of different composition and age) as well as their confined occurrence as lenticular intercalations within the Lower Malm strata allows the conclusion that they represent true karst breccias. Consequently, they are interpreted to be the lateral equivalents of a bauxite horizon which often is intercalated between the Lower and Upper Malm beds in the Dinarids and is also present nearby the investigated carbonate succession (Bus er, 1987 pers. com.).

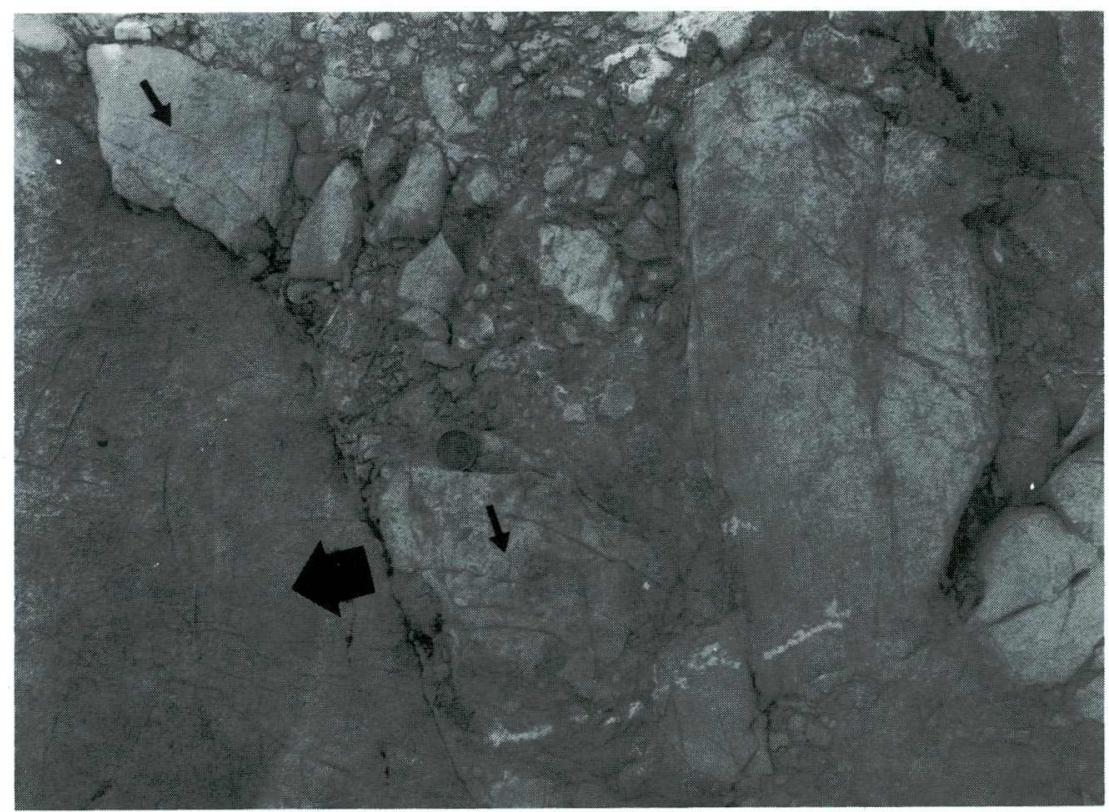

Fig. 5. Karst breccia with clasts of Lower Malm (thick arrow: ooid grainstones) and Upper Malm (thin arrows: mudstones and fossil wackestones). Section 2

\section{Upper Malm}

The boundary between Lower and Upper Malm (Fig. 4, Appendix: section 2, g) is drawn beneath the uppermost (last) breccia which is of more monomict composition (mudstones and fenestral mudstones). Clasts with typical Lower Malm carbonates 
(ooid grainstones and oncoid packstones) are missing. Unfortunately, the underlying as well as the superposed carbonates are strongly to completely dolomitized. It may therefore be possible that also this boundary is actually situated a little bit lower within the underlying dolomites. At any rate, only the dolomites above the last breccia show the typical cryptalgal lamination (»cryptalgalaminate carbonates"; Aitken, 1967) which seems to be indicative for the Upper Malm (Strohmenger, 1988). Determinable index fossils (Campbelliella striata (Carozzi) Bernier, Clypeina jurassica Favre, Salpingoporella annulata Carozzi) could only be found within the dolomites situated above the last breccia (in the less dolomitized parts). Therefore, it seems to be appropriate to define the boundary with the last occurence of the karst breccia.

The Upper Malm is mostly developed in the form of bedded and partly stromatolitic dolomites. Only the last $35 \mathrm{~m}$ of the section (including Lower Cretaceous beds) are built up of pure limestones (Fig. 4, Appendix: section 2, h). The lowermost parts of these limestones contain the alga Clypeina jurassica Favre, Salpingoporella annulata Carozzi and Campbelliella striata (Carozzi) Bernier (Pl. 2, Fig. 4).

The boundary between the Upper Malm and the Lower Cretaceous is somewhat controversial in the Dinarids. Some authors are drawing the boundary either with the appearance of the aberrant Tintinnids (R a d o i č i ć, 1960,1966), after the extinction of Clypeina jurassica (B us er, 1968, 1979; Turnš ek \& Bus er, 1966) or a little bit later after the extinction of the aberrant Tininnids (S o ka č et al, 1978; Sri bar, 1979a, b). A compilation of the literature concerning this problem is given by $\mathrm{S}$ ri b a r (1979b) and Ko ch (1987). Nevertheless, one has to take into consideration that these microfossils are also facies dependent ( $\mathrm{R}$ a d o i č i ć, 1969). Only minor changes in the environment may be responsible for a diachronous appearance or extinction of the different algae. The investigated carbonates show no marked facies changes; for this reason we place the boundary between the Upper Malm and the Lower Cretaceous after the last appearance of the aberrant Tintinnids (which lies only about $4 \mathrm{~m}$ above the extinction of Clypeina jurassica Favre).

\section{Lower Cretaceous (Berriasian)}

The directly superposed limestones $(9 \mathrm{~m})$ are free of index fossils but rich in gastropods (Nerineae) and algal laminated, fenestral carbonate deposits at the top (Fig. 4, Appendix: section 2, h). Above this series, within the uppermost exposed beds (about $7 \mathrm{~m}$ ) of the section, an index fossil of the Lower Creataceous Clypeina solkani Conrad \& Radoičić could be identified (Pl. 2, Fig. 2). The beds containig Clypeina solkani as well as the underlaying limestones (totally about $16 \mathrm{~m}$ ) are therefore supposed to be of Berriasian age.

\section{Lithology}

Section 2 is built up predominantly by limestones, but the content of dolomites is much higher than in section 1. Large parts of the Lower Lias and the Upper Malm are nearly completely formed by thick dolomite beds. In addition, the carbonate rocks of the Lower Dogger (ooid grainstones) and Lower Malm (ooid grainstones, karst breccias) are often laterally dolomitized. The dolomitized areas frequently show a brecciated texture.

The thickness of the beds lies in the same range as for section 1 . 


\section{Geochemistry}

The determined values of $\mathrm{Mg}, \mathrm{Sr}, \mathrm{Fe}, \mathrm{Mn}, \mathrm{K}$ (section 1 and 2) as well as $\mathrm{Zn}$ (section 2) and $\mathrm{Al}$ (section 2) in the investigated calcareous rocks demonstrate a significant facies dependence:

- relative high contents of all elements are typical for calcareous rocks of lagoonal deposits (e. g. mudstones and wackestones)

- high energy deposits (e. g. ooid grainstones) are, on the contrary, markedly depleted in these elements.

The valeus of manganese and strontium are in some cases relatively low. The loss of these elements might be explained by diagenetic processes.

The insoluble residue shows a good correlation with iron, manganese, potassium and aluminium.

The measured elements in the two investigated sections reflect the environmental conditions under which the calcareous rocks were deposited.

Similar geochemical results appear also in other Jurassic sections of the Slovenian Dinaric carbonate platform (Orehek \& O gorelec, 1979, 1981). According to the literature they are within the general limits of calcareous rocks.

\section{Conclusions}

Section 1: the age of the carbonates above the beds containing definite index fossils of the Lower Dogger is very uncertain (except for those of the Upper Malm). The abundance of the foraminifer Palaeosiphonium convolvens points to Dogger age for most of these carbonates (including a large proportion of the oolits). Nevertheless, there are also hints for Lower Malm ages such as the occurrence of the alga Heteroporella anici and the abundance of corals and hydrozoans (Cladocoropsis mirabilis) within these carbonate beds. In addition, it cannot be excluded that under siutable environmental conditions (e. g. restricted lagoon) Praekurnubia sp. can also be frequent in Oxfordian and Lower Kimmeridgian carbonates, even when Kurnubia $\mathrm{sp}$. is missing. We therefore propose not to change the stratigraphy presented by Strohmenger (1988), but to point to the possibility that the carbonates described as Lower Malm might be partly of Dogger age, or respectively, that the range of Praekurnubia sp. and Palaeosiphonium convolvens reaches also into the Lower Malm (Kimmeridgian?) and therefore should be reinvestigated.

Section 2: the studied Jurassic carbonate rocks clearly indicate a stratigraphical gap during the Dogger. The index fossils which could be identified point to an age older than Callovian or older than Upper Callovian respectively. Perhaps the break in sedimentation coincides with the assumed fall of sea level during the Callovian or at the end of the Bathonian (Hallam, 1987, 1988; Bossellini et al., 1981). The identified karst breccia (intercalated within Lower Malm carbonate rocks) contains clasts of both Lower and Upper Malm. It therefore indicates a long-term emergence of the carbonate platform during the Upper Malm.

The results of the geochemical analyses must be treated with care because of the extensive fracturing of the carbonates. In relation to the sediment textures and structures they are however useful indicators of the water conditions under which the carbonates were formed. 


\section{Acknowledgments}

This study is based on the Ph. D. dissertation of the senior author and would not have been possible without the support and cooperation of Prof. Dr. G. Müller (Institut für Sedimentforschung, Heidelberg) and prof. Dr. R. Koch (Institut für Paläontologie, Erlangen). The authors greatfully acknowledge Dr. R. Radoičić and B. Sc. L. Sribar for the determination of the foraminifera and algae, as well as Dr. D. Turnšek for the determination of the corals and hydrozoans. C. Strohmenger thanks Dr. M. Septfontaine for the stimulating discussion and the determination of some foraminifera. The senior author is particularly indepted to the Geološki Zavod Ljubljana for providing access to the study area and for the financial support during the field work. A very special acknowledgment from C. Strohmenger is extended to Prof. Dr. S. Buser for his guidance, encouragement and helpful comments. We also wish to thank Dr. A. Strasser for his critical review.

\section{Lit erature}

A itken, J. D. 1967, Classification and environmental significance of cryptalgal limenstones and dolomites, with illustrations from the Cambrian and Ordovician of southwestern Alberta. - J. Sed. Petrol. 37/4, 1163-1178, 22 Figs., Tulsa.

Allemann, F. \& Schroeder, R. 1972, Spiroconulus perconigi n.gen. n.sp. A. new Middle Jurassic foraminifer of Oman and Spain. - Rev. Esp. de Micropaleont. Núm. Extra. XXX, 199-209, 2 Figs., 3 Pls., Madrid

Allemann, F. \& Schroeder, R. 1980, Spiraloconulus nom. nov. for Spiroconulus Allemann \& Schroeder 1972 (Foraminiferida). - Rev. Esp. de Micropaleont. 12/3, 358, Madrid.

Bernier, P. 1974, Campbelliella striata (Carozzi): Algue dasycladacée? Une nouvelle interprétation de l'»Organisme C « Favre et Richard, 1927. - Géobios 7/2, 155-175, 6 Figs., 3 Pls., Lyon.

Bosellini, A., Masetti, D. \& Sari, M. 1981, A Jurassic "Tongue of the Ocean« infilled with oolitic sands: The Belluno Trough, Venetian Alps, Italy. - Marine Geol. 44, 59-95, 25 Figs., Amsterdam.

Buser, S. 1968, The development of Jurassic strata in the Outer Dinarids of Slovenia. - First Coll. Geol. Dinaric Alps. Geol. Survey and Geol. Society of Slovenia 1, 59-67, Ljubljana.

Bus er, S. 1974, Tolmač k Osnovni geološki karti SFRJ list Ribnica 1:100.000. - Zvezni geol. zavod Beograd, 50 p., Beograd.

Buser, S. 1979, Jurassic beds in Slovenia. - In: Drobne, K. (ed.): 16 th European Micropaleontological Colloquium. Geol. Dev. in Slovenia and Croatia. - Guide Book, 27-36, 1 Fig., Ljubljana.

Elliott, G. F. 1977, Inferred isocrymal distribution of Jurassic dasycladacean algae in Europe, north Africa and southwestern Asia. - J. geol. Soc. London 133, 363-373, 6 Figs., London.

Elliott, G. F. 1985, Palaeosiphonium, a problematic Jurassic alga. - Bull. Br. Mus. nat. Hist. (Geol.) 38/5, 283-286, 4 Figs., London.

Gušić, I. 1969, Some New and inadequatly known Jurassic foraminifers from Central Croatia. - Geol. vjesnik 22, 55-177, 15 Pls., Zagreb.

Hagen, D. \& Kemper, E. 1976, Geology of the Thong Pha Phum Area (Kanchanaburi Province, western Thailand). - Geol. Jb. 21, 53-91, 5 Figs., 7. Pls., Hannover.

Hallam, A. 1978, Eustatic cycles in the Jurassic. - Palaeogeogr. Palaeoclimatol. Palaeoecol. 23, 1-32, 11 Figs., Amsterdam.

$\mathrm{Hallam}$, A. 1988, A reevaluation of Jurassic eustasy in the light of new data and the revised Exxon curve. - In: Wilgus, C. K., Hastings, B. S. Kendall, C. G. St. C., Posamentier, H. W., Ross, C. A. \& Van Wagoner, J. C. (eds.): Sea-level changes: an integrated approach. - SEPM Spec. Publ. 42, 261-273, 10 Figs., 1 Tab., Tulsa.

Kemper, E. 1976, The foraminifera in the Jurassic limestone of west Thailand. - Geol. Jb. 21, 129-153, 1 Tab., 4 Pls., Hannover. 
Kemper, E., Maronde, H.-D. \& Stoppel, D. 1976, Triassic and Jurassic limestone in the region northwest and west of Si Sawat (Kanchanaburi Province, western Thailand). - Geol. Jb. 21, 93-127, 1 Fig., 1 Tab., 6 Pls., Hannover.

K och, R. 1987, Mikrofazielle und diagenetische Entwicklung kretazischer Karbonatgesteine im jugoslawischen Raum. - Habilitationsschrift, 214 p., 90 Abb., Heidelberg.

Moullade, M., Haman, D. \& Huddleston, R. W. 1981, Gutnicella, a new name for Lucasella Gutnic and Moullade, 1967 (foraminiferida) non STEWART, 1936 (ostracoda). - J. Paleont. 55/2, 484, Tulsa.

Orehek, S. \& Ogorelec, B. 1979, Sedimentologic features of the Jurassic and Cretaceous carbonate rocks of Trnovski Gozd. Geol. vjesnik 32, 185-192, Zagreb.

Orehek. S. \& Ogorelec, B. 1981, Correlation of microfacial and geochemical characteristics of Jurassic and Cretaceous rocks of the southern carbonate platform in Slovenia. Glas. republ. zav. zašt. prir. - Prir. muzeja (Titograd) 14, 161-181, Titograd.

Radoičić, R. 1960, Mikrofacije krede i starijeg tercijara spoljnih Dinarida Jugoslavije. - Paleont. Jugosl. Dinarida, (A), 4/1, 35 p., Titograd.

R a d oičić, R. 1966, Microfaciès du Jurassique des Dinarides externes de la Yougoslavie. - Geologija 9, 5-377, 165 Pls., 11 tab., 2 supps., Ljubljana.

R a d o ičić, R. 1969, Aberantna grana fosilnih Tintinina (Podred Tintinnina). La branche aberrante des Tintinnines fossiles (Sous-Ordre Tintinnina). - Palaeont. Jugosl. 9, 5-71, 31 Figs., $8 \mathrm{Pls}$., Zagreb.

Redmond, C. D. 1964, The foraminiferal family Pfenderinidae in the Jurassic of Saudi Arabia. - Micropaleont. 10/2, 251-263, 1 Tab., 2 Pls., New York.

Septfontaine, M. 1988, Vers une classification évolutive des Lituolides (foraminiferes) Jurassiques en milieu de plate-forme carbonatée. - Rev. Paléobiol. Vol. Spéc. 2, 229-256, 5 Figs., $2 \mathrm{Pl}$. Genève.

Sokač, B., Velić, I. \& Tišljar, J. 1978, A model of biostratigraphic subdivision and an interpretation of depositional environments in the Lower Cretaceous carbonate sediments of Biokovo mountain (south Croatia). - Zbornik radova, IX. kongr. geol. Jugosl., 226-232, 1 Fig., Sarajevo.

Strohmenger, C. 1988, Mikrofazielle und diagenetische Entwicklung jurassischer Karbonate (Unter-Lias bis Ober-Malm) von Slowenien (NW Jugoslawien). - Heidelberger Geowiss. Abh. 24, 293 p., 59 Abb., 16 Taf., 12 Tab., Heidelberg.

Strohmenger, C., Dozet, S. \& Koch, R. 1987a, Oolith-Sequenzen im Jura SüdwestSloweniens (Mala Gora-Gebirge, Ober-Lias bis Ober-Malm). - In: Koch, R., Müller, G. \& Schmitz, W. (eds.): Heidelberger Geowiss. Abh. 8, 245-248, 3 Abb., Heidelberg.

Strohmenger, C., Dozet, S. \& Koch, R. $1987 \mathrm{~b}$, Diagenesemuster-Stratigraphie: Oolith-Horizonte im Jura von SW-Slowenien. - Facies 17, 253-266, 5 Abb.,2 Taf., Erlangen.

Sribar, L. 1979 a, Biostratigraphy of the Jurassic-Cretaceous boundary layers from south Slovenia. - Geologija 22/1, 113-116, Ljubljana.

Sribar, L. 1979 b, Biostratigraphy of Lower Cretaceous beds from the Logatec plain. - Geologija 22/2, 277-308, 2 Figs., 9 Pls., Ljubljana.

Turnšek, D. \& Buser, S. 1966, The development of the Lower Cretaceous beds and the boundary between Jurassic and Cretaceous formations in the western part of Trnovski Gozd - Geologija 9, 527-548, 1 Fig., 6 Tab., 2 Pls., Ljubljana.

\section{Plate 1}

1 Palaeodasycladus elongatus Praturlon, $\times 16$. Lower Lias, thin section; section 2

2 Orbitopsella praecursor Gümbel, $\times 40$. Middle Lias, thin section; section 2

3 Mayncina termieri Hottinger, $\times 40$. Middle Lias, thin section; section 2

4 Dictyoconus cayeuxi Lukas, $\times 40$. Dogger, thin section; section 2 

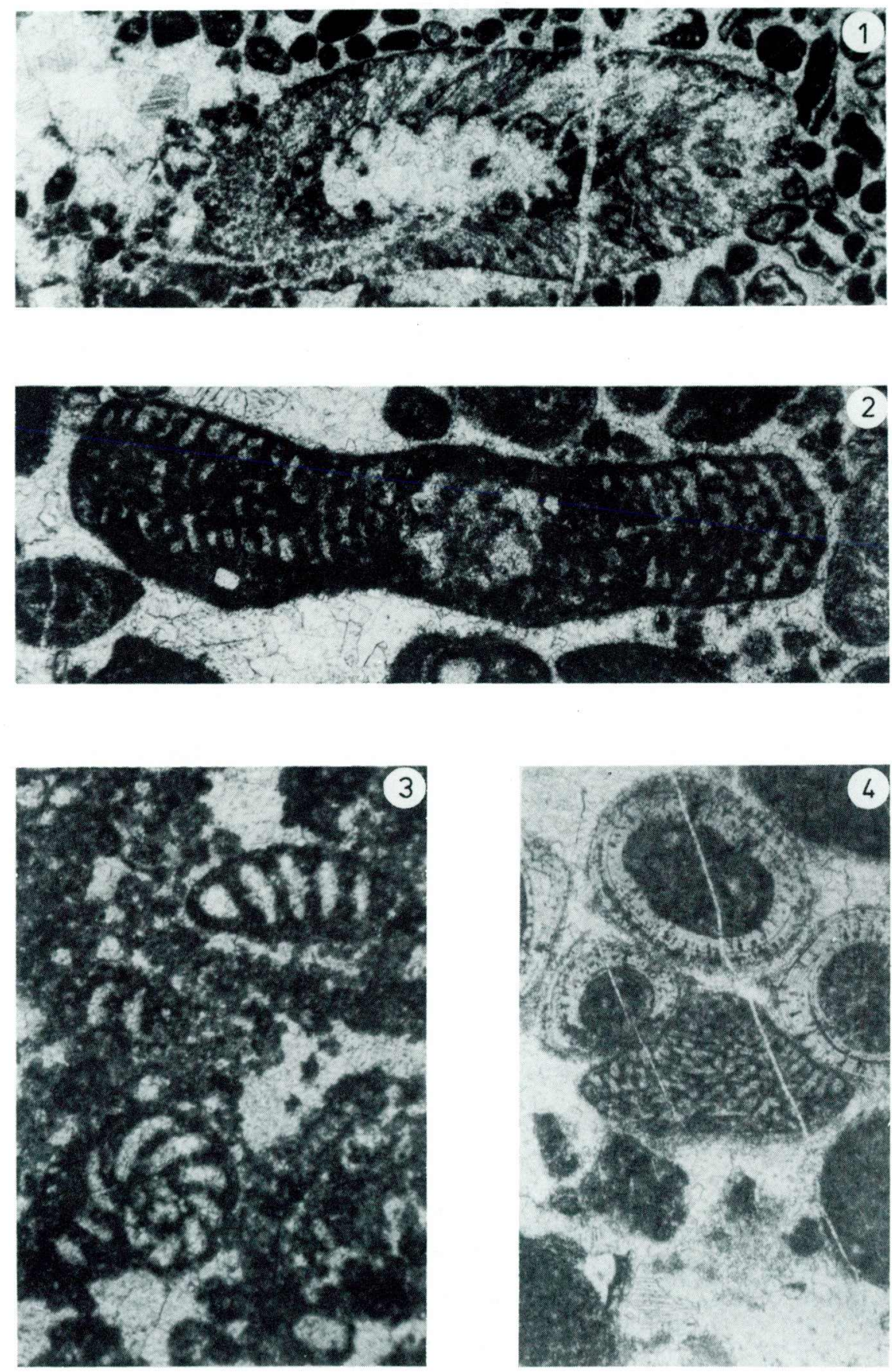


\section{Plate 2}

1 Heteroporella anici Nikler \& Sokač, $\times$ 40. Lower Malm 1 (Kimmeridgian?), thin section; section 1

2 Clypeina? solkani Conrad \& Radoičić and Miliolid foraminifer, $\times$ 40, Lower Cretaceous (Berriasian); section 2

3 Parurgonina caelinensis Cuvillier (left) and Clypeina jurassica Favre (right), $\times 40$. Upper Malm, thin section; section 1

4 Campbelliella striata (Carozzi) Bernier (aberrant Tintinnids), $\times 16$. Upper Malm, thin section; section 2 

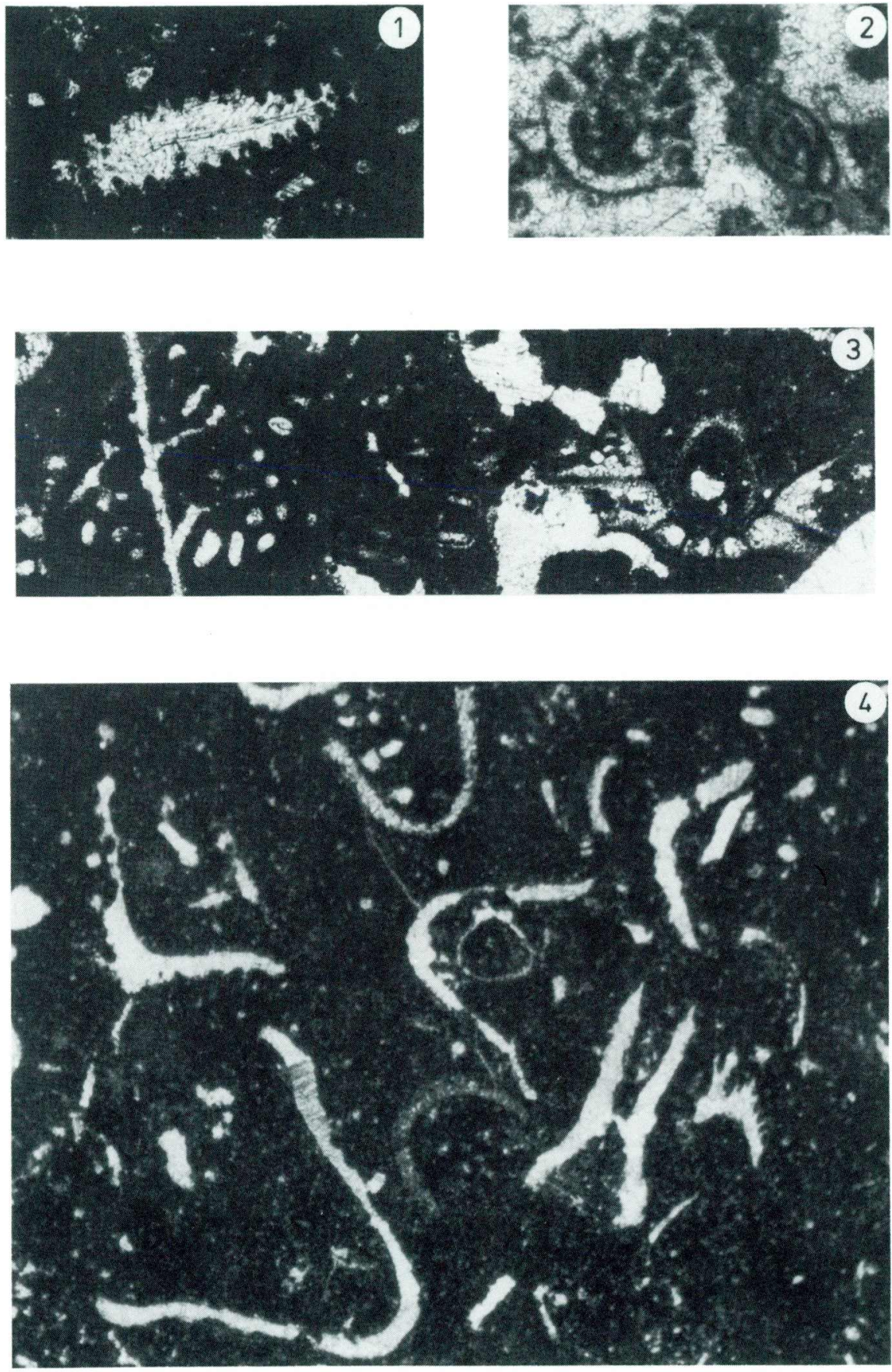
Explanation to the sections 1 and 2

L I T H $\mathrm{O}$ L $O$ G $\mathrm{G}$

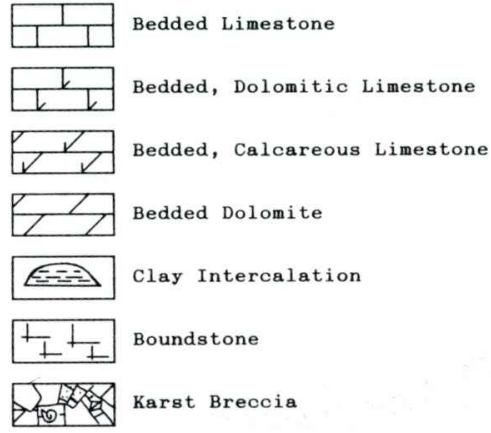

M I N

Calcite

Dolomite

Insoluble Residue

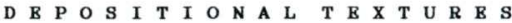

M Mudstone

w Wackestone/Floatstone

P Packstone

G Grainstone/Rudstone

B Boundstone

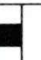

Unequivocal Texture (e.g. Grainstone

ated Textures

(e.g. Wackestone and Packstone)

24

Dominant/Subordinate Texture

Dominant Texture with thin Intercalations (e.g. mud drapes)

Presumed Texture

4 (e.g. strongly dolomitized limestones)

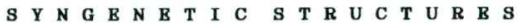

- cm-lamination

”mm-lamination

$s$ mm-lamination induced by algae/bacteria $\approx$ crypalgal lamination (crinckled bedding)

ఋ presumed cryptalgal lamination

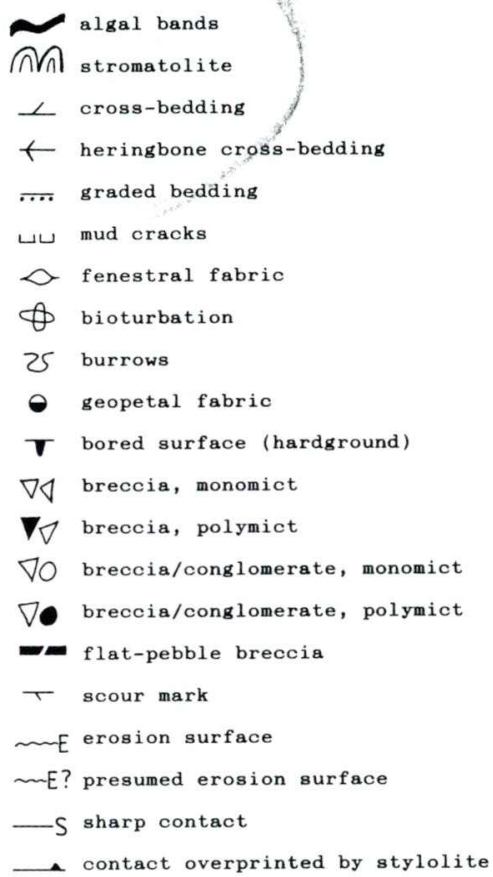

B P I G E N E T I C $\quad$ S T R U C T U R B S

moderately fractured

3) strongly fractured

3) very strongly fractured

$3_{C / D}$ with calcite/dolomite filled fracture

- stylolite

- contact overprinted by stylolite

$\tau$ horge-tailing

$\nabla \checkmark$ breccia, monomict

$\nabla 4$ breccia, polymict

$\nabla 0$ breccia/conglomerate, monomict

$\nabla 0$ breccia/conglomerate, polymict

Qz quartz

Py pyrite

$\longrightarrow$ fault

$\ldots$ - $\rightarrow$ presumed fault 
C O M P O N B T $\mathbf{S}$

(1) Micritic intraclasts (round/angular) without internal texture $<4 \mathrm{~mm}$

(1) (1) Micritic intraclasts (round/angular) without internal texture > $4 \mathrm{~mm}$

$\ominus \ominus$ Intraclasts (round/angular) with internal texture $<4 \mathrm{~mm}$

$\theta \theta$ Intraclasts (round/angular) with internal texture > $4 \mathrm{~mm}$

(0) Cortoids

○○ Ooids

(D) Oncoids

$\because$ Peloids

(g) Fossils (undiff.)

F O S S I I L S

$\$$ Foraminifera (undiff.)

Dictyoconus cayeuxi

Orbitopsella praecursor

H Algae (undiff.)
(2) Palaeodasycladus mediterraneus

(0) Palaeosiphonium convolvens

- Salpingoporella annulata

$\sqrt{\text { CIypeina jurassica }}$

4 Clypeina solkani

$\bigvee$ Campbelliella striata

(1) Thaumatoporella parvovesiculifera

W Hydrozoa (undiff.)

OD cladocoropsis mirabilis

(3) Corals

Un Gastropods

- Bivalves

Fhell Accumulation (thin)

$\longrightarrow$ Lithiotids

(D) Ostracods

fy Bryozoans

$\nabla$ Brachiopods

D Echinoderms 
SECTION 1 (a, base)

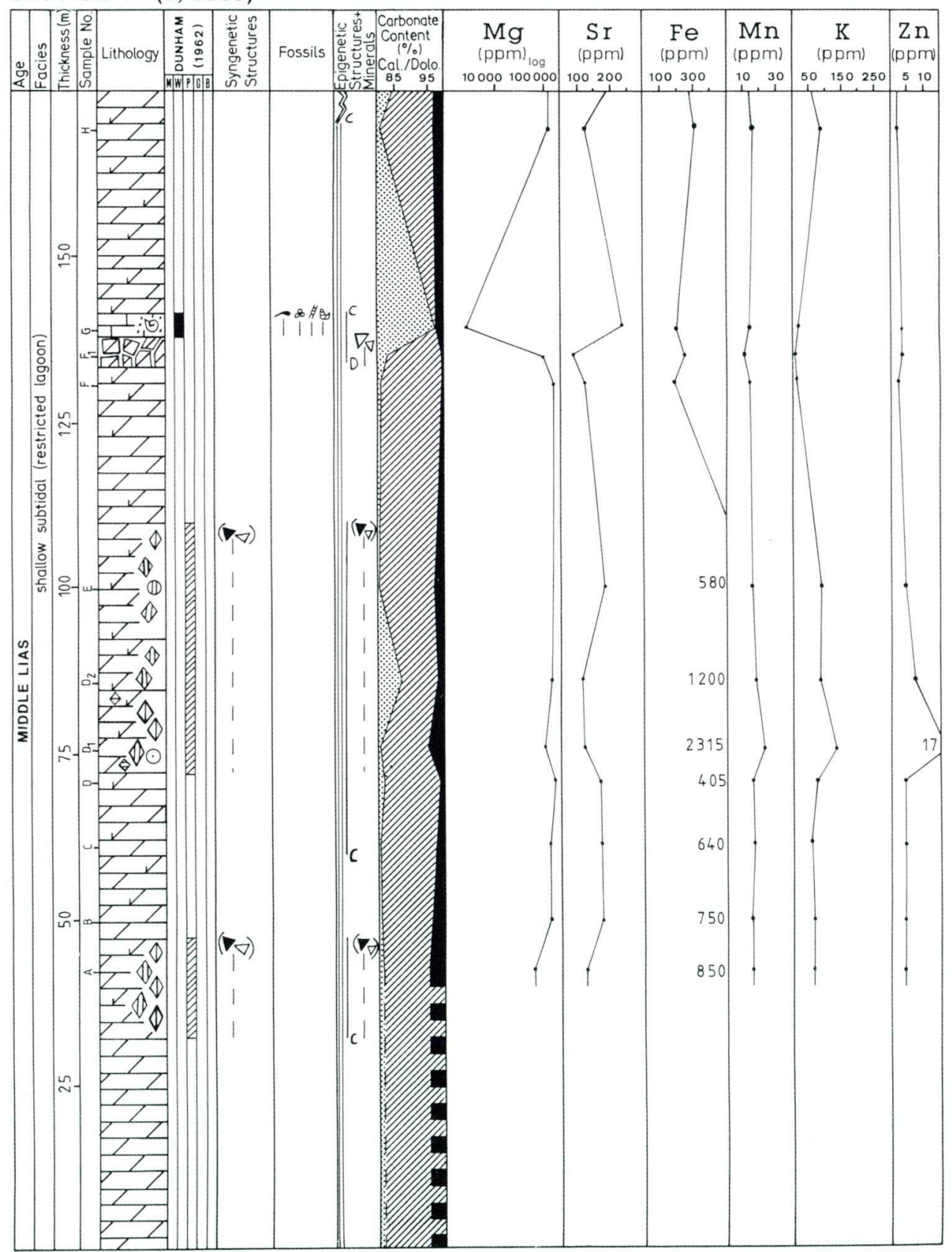


SECTION 1 (b)

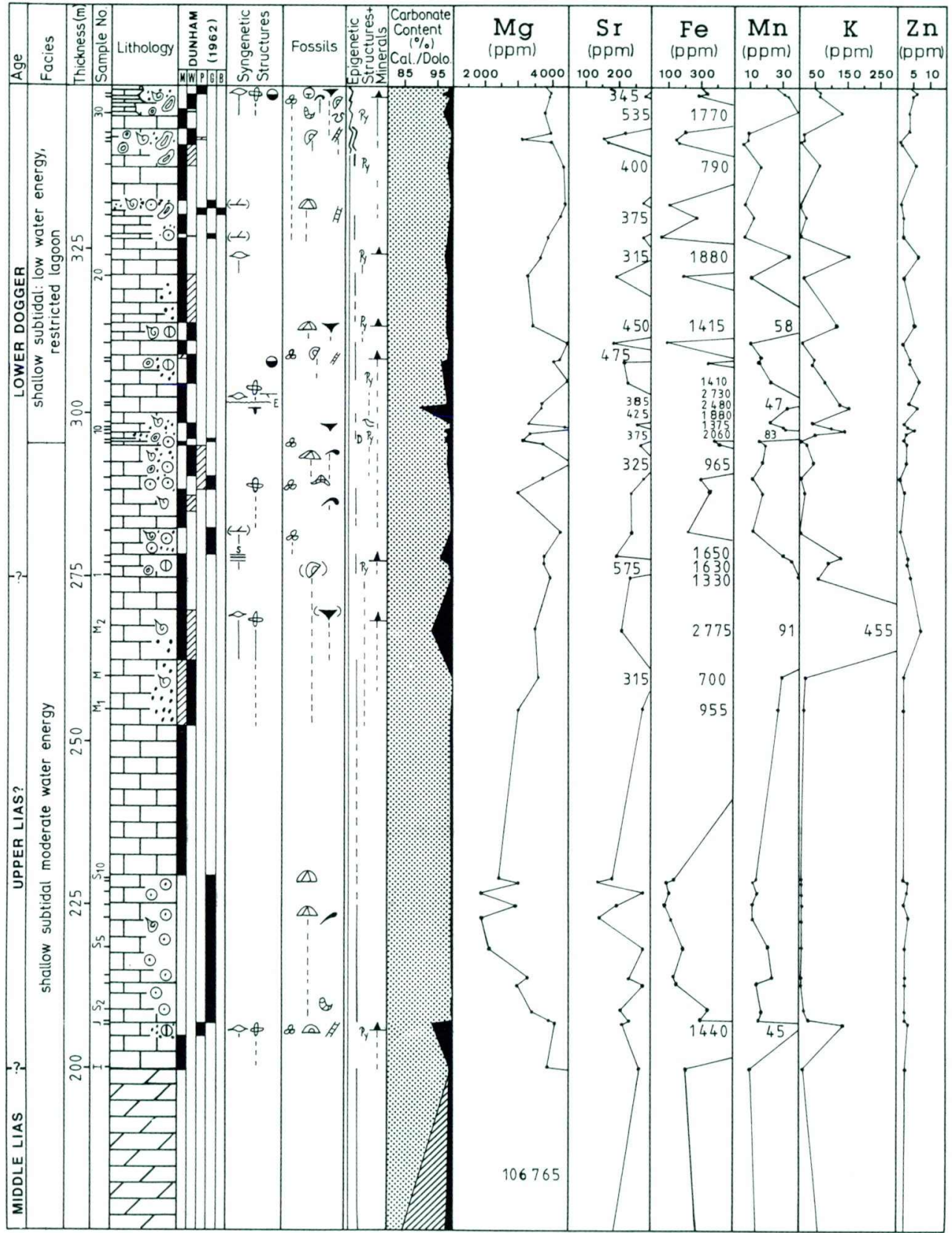


SECTION 1 (c)

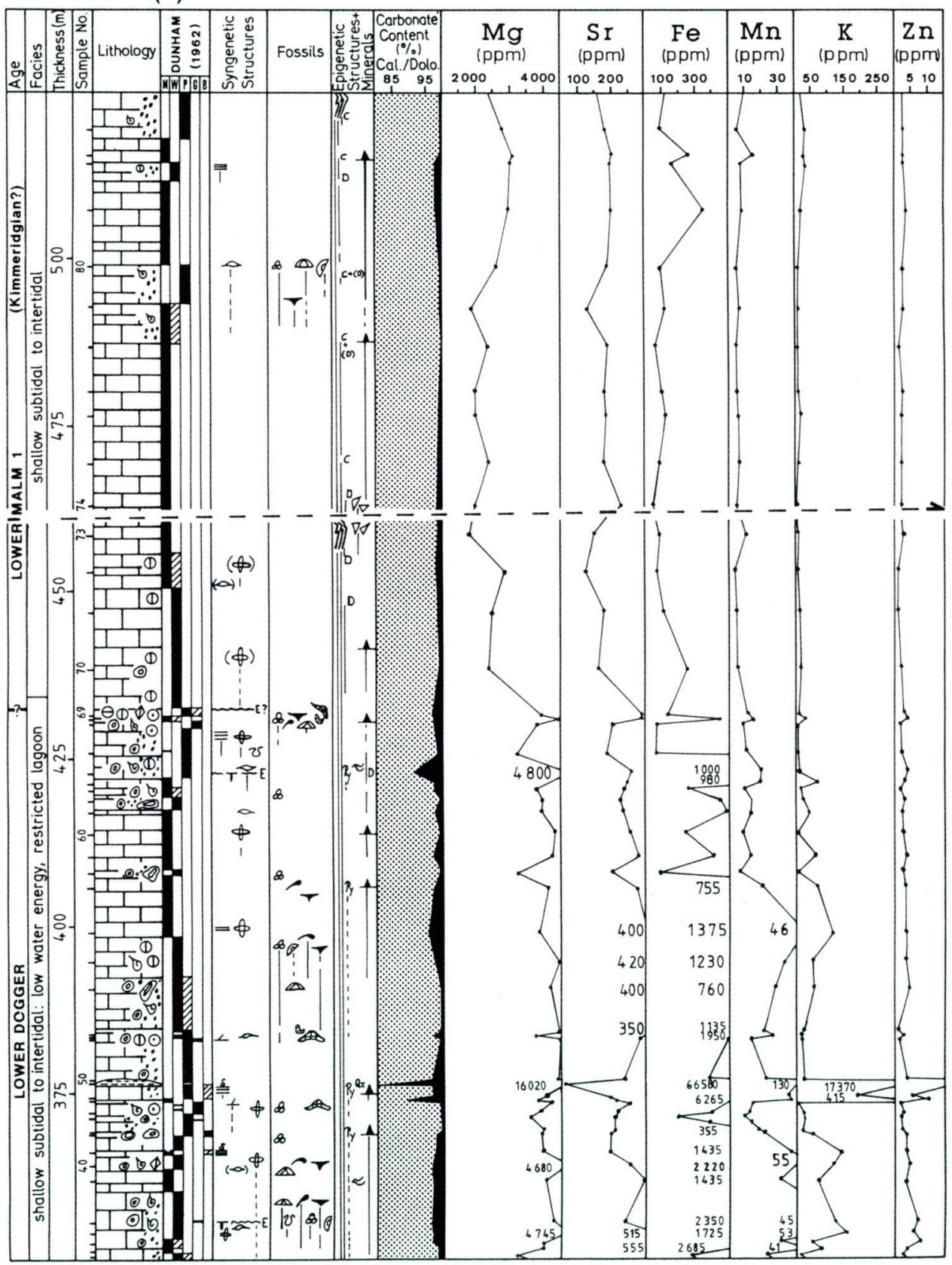


SECTION 1 (d)

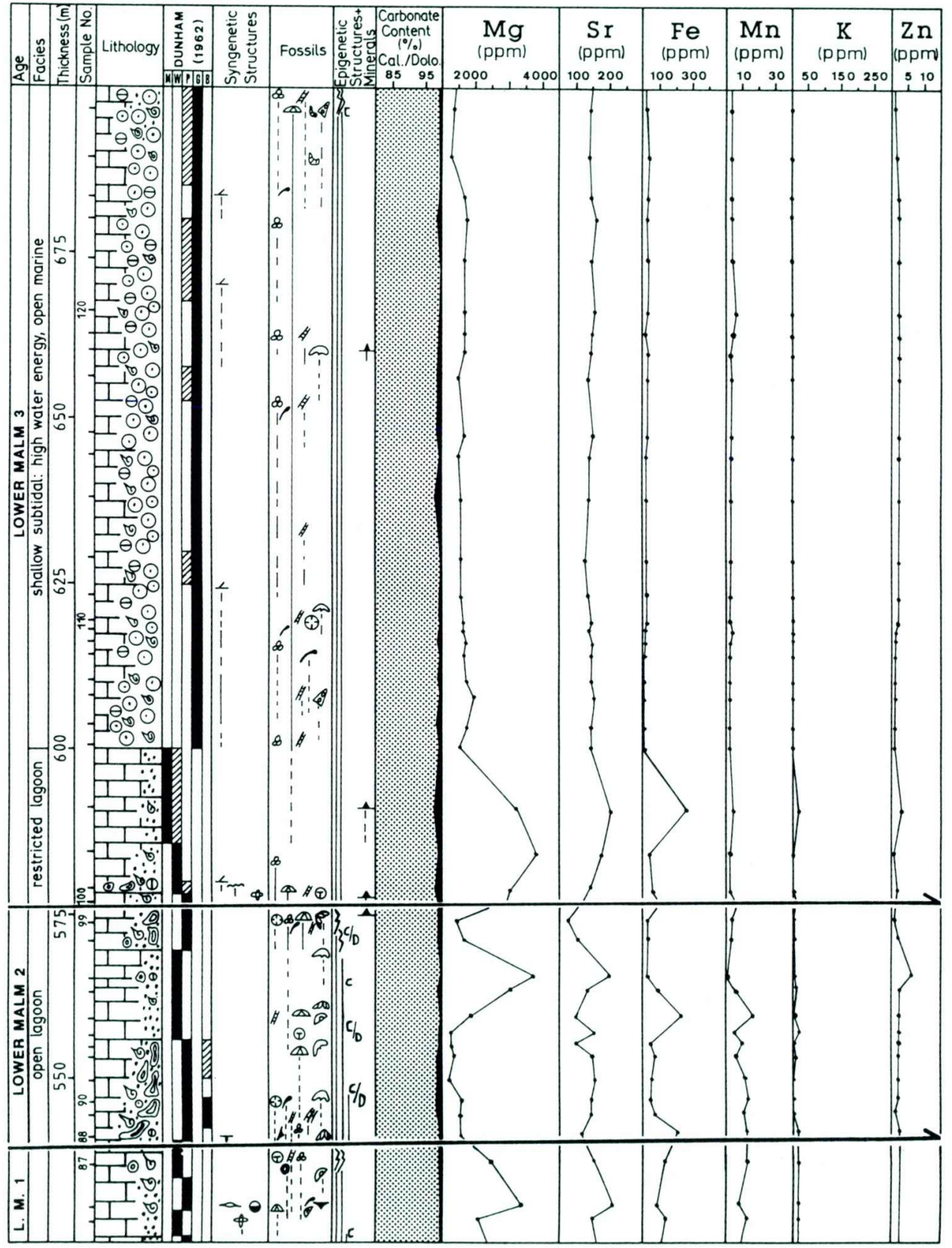


SECTION 1 (e)

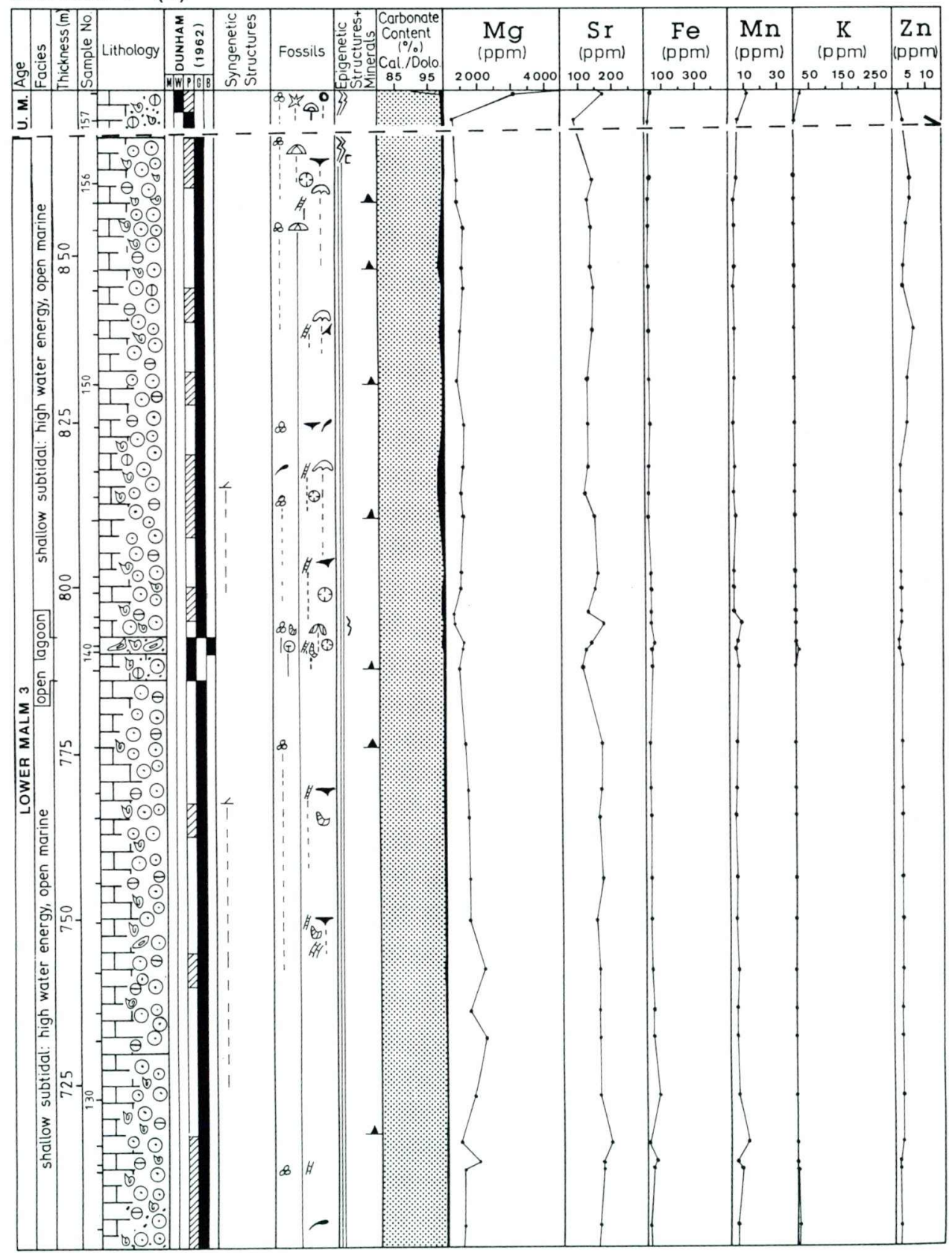


SECTION 1 (f)

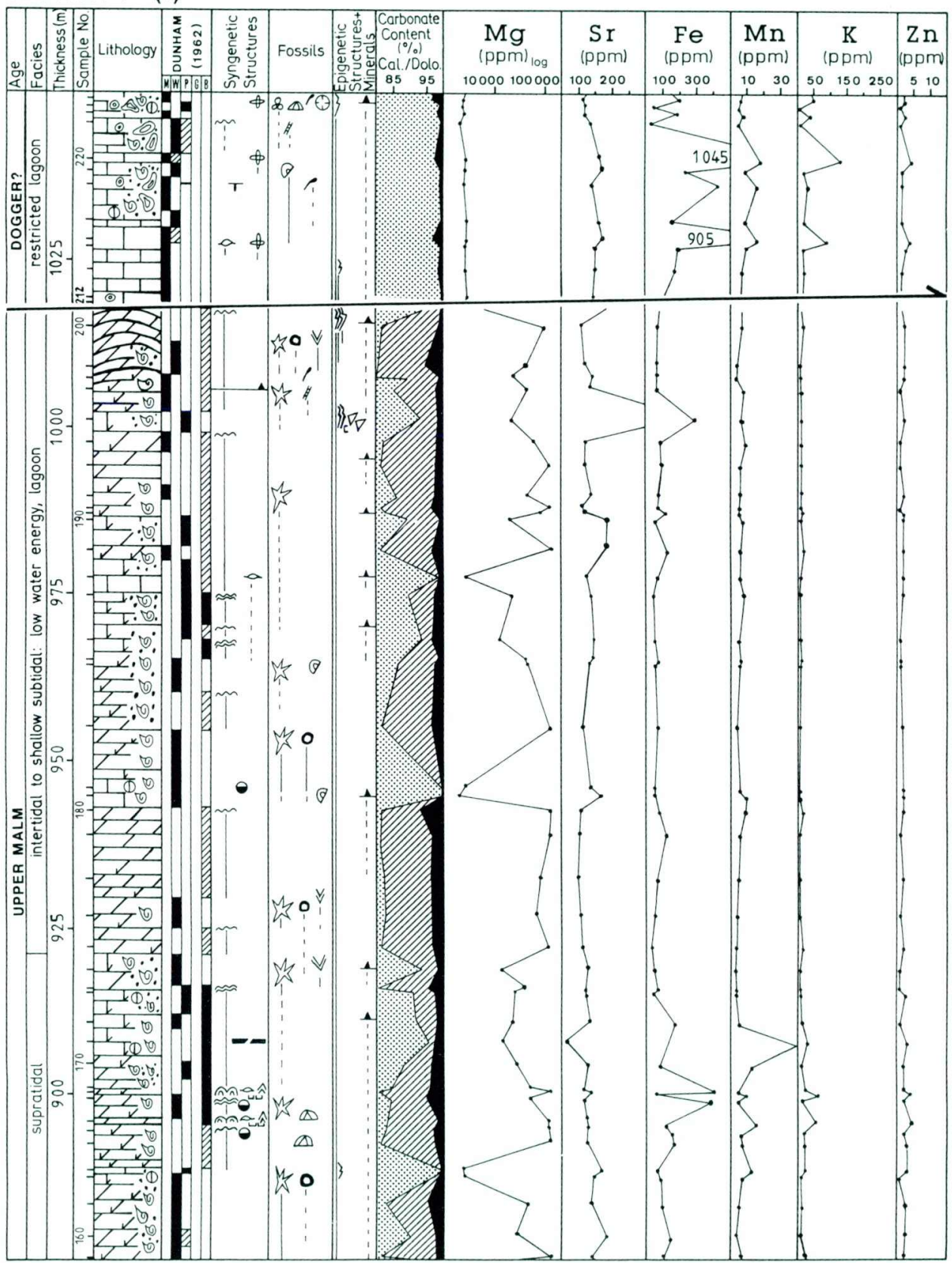


SECTION 1 (g)

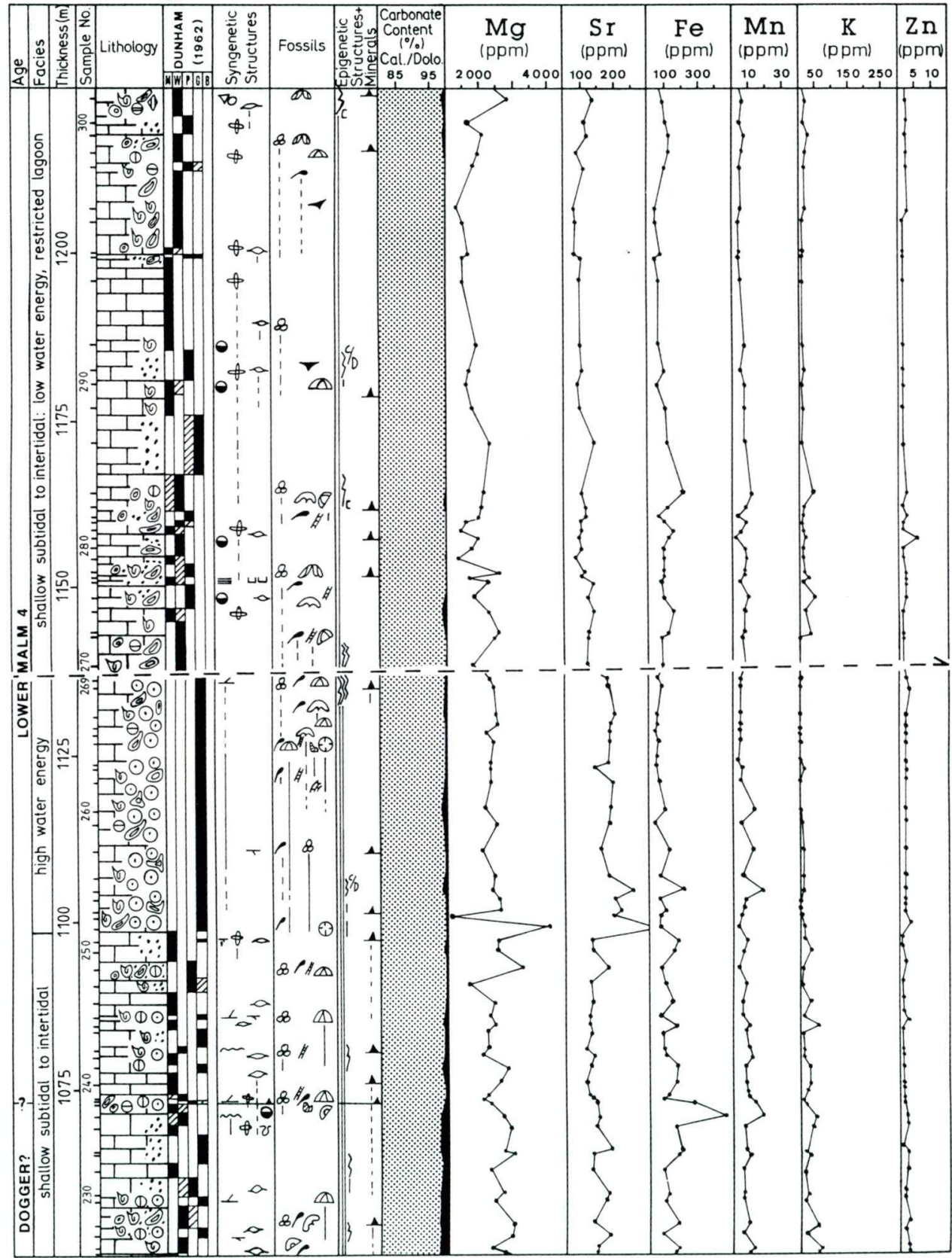


SECTION 1 (h, top)

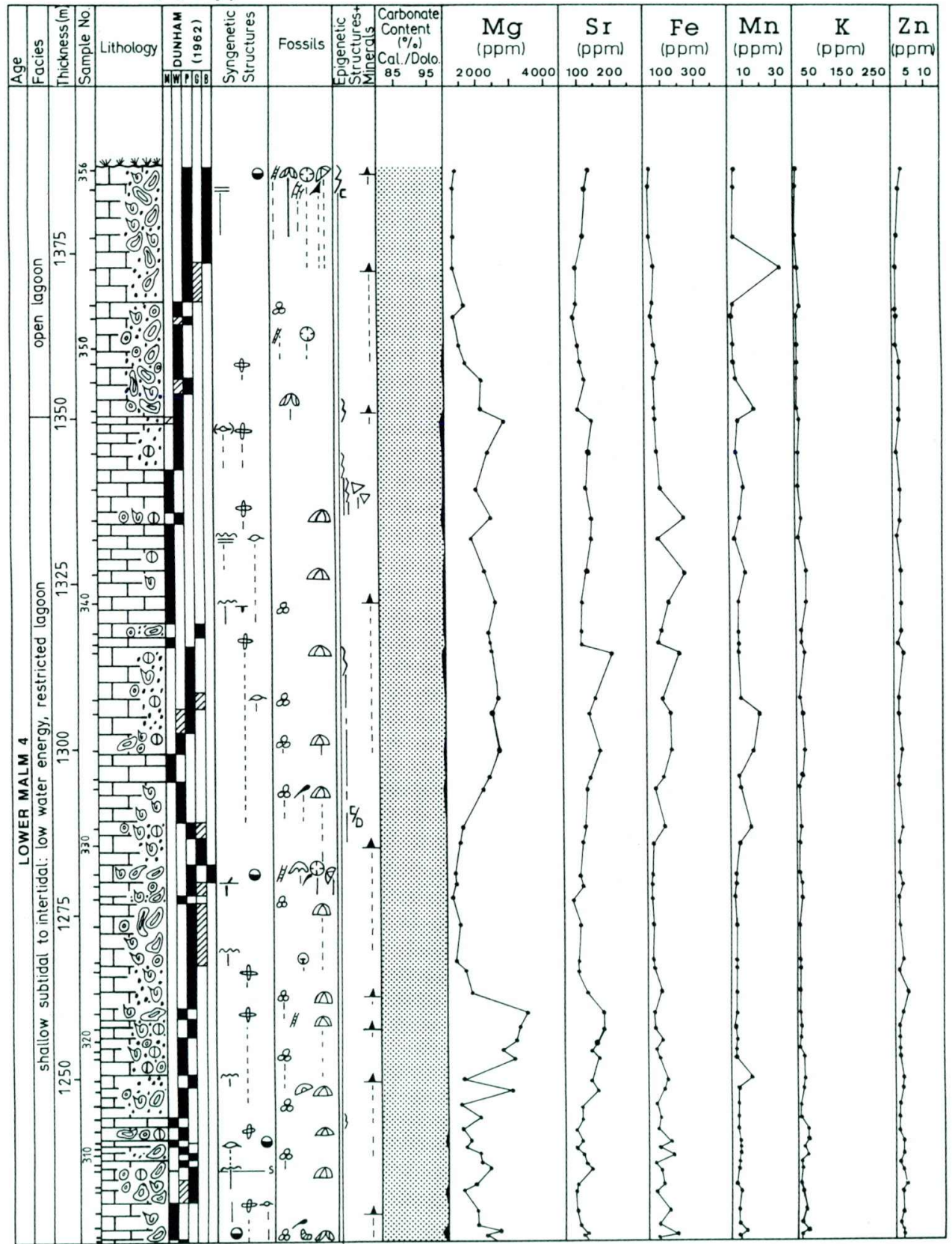


SECTION 2 (a, base)

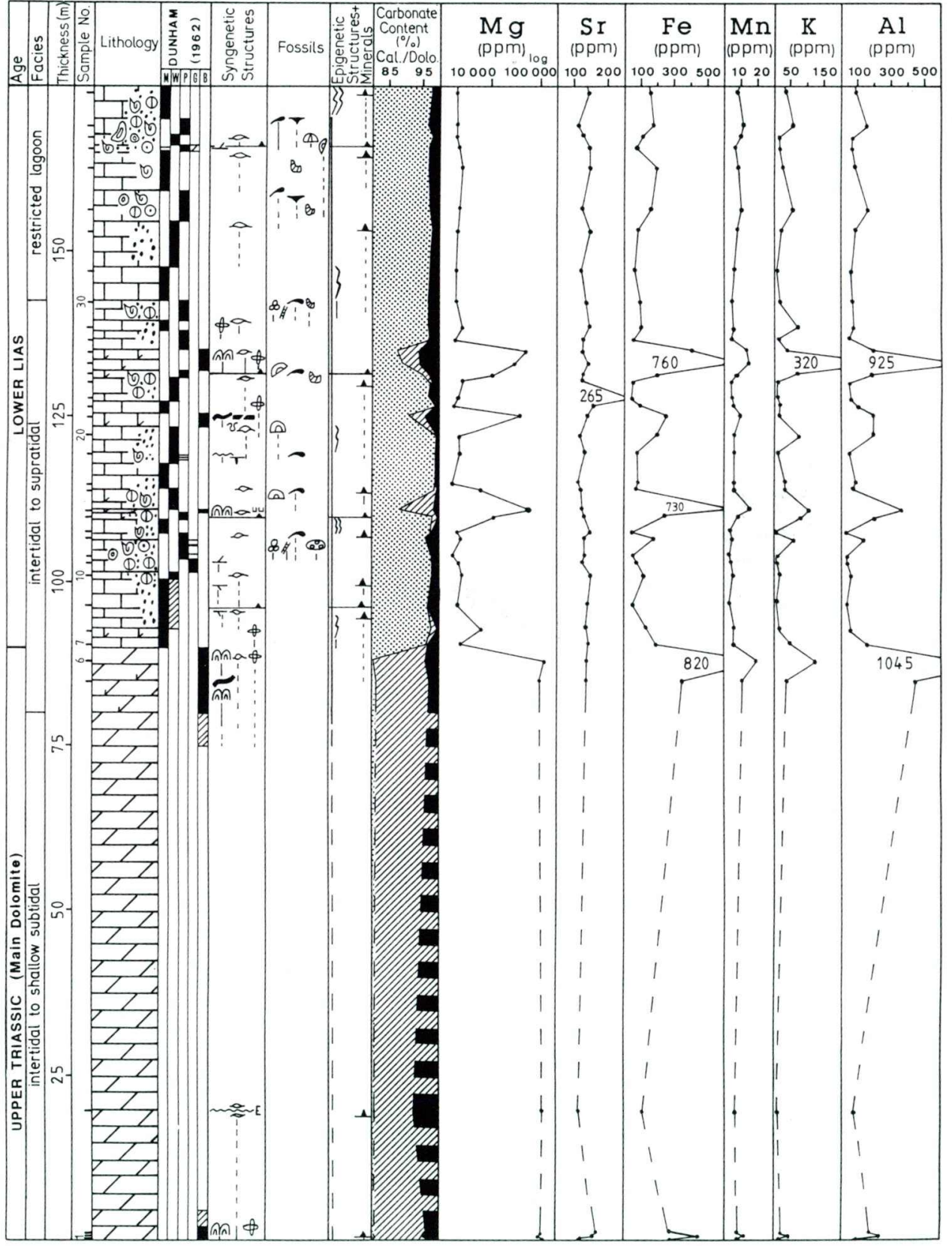


SECTION 2 (b)

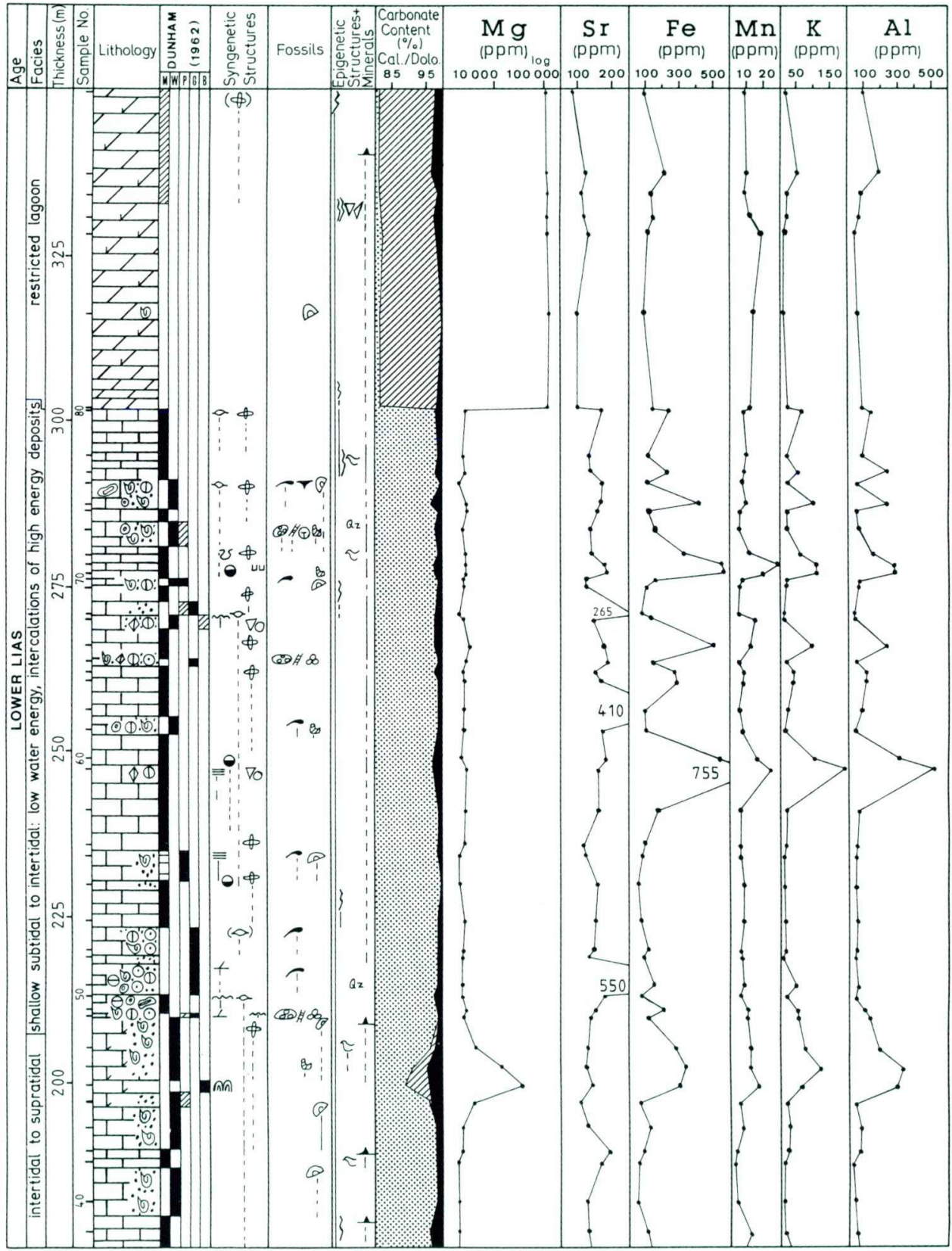


SECTION 2 (c)

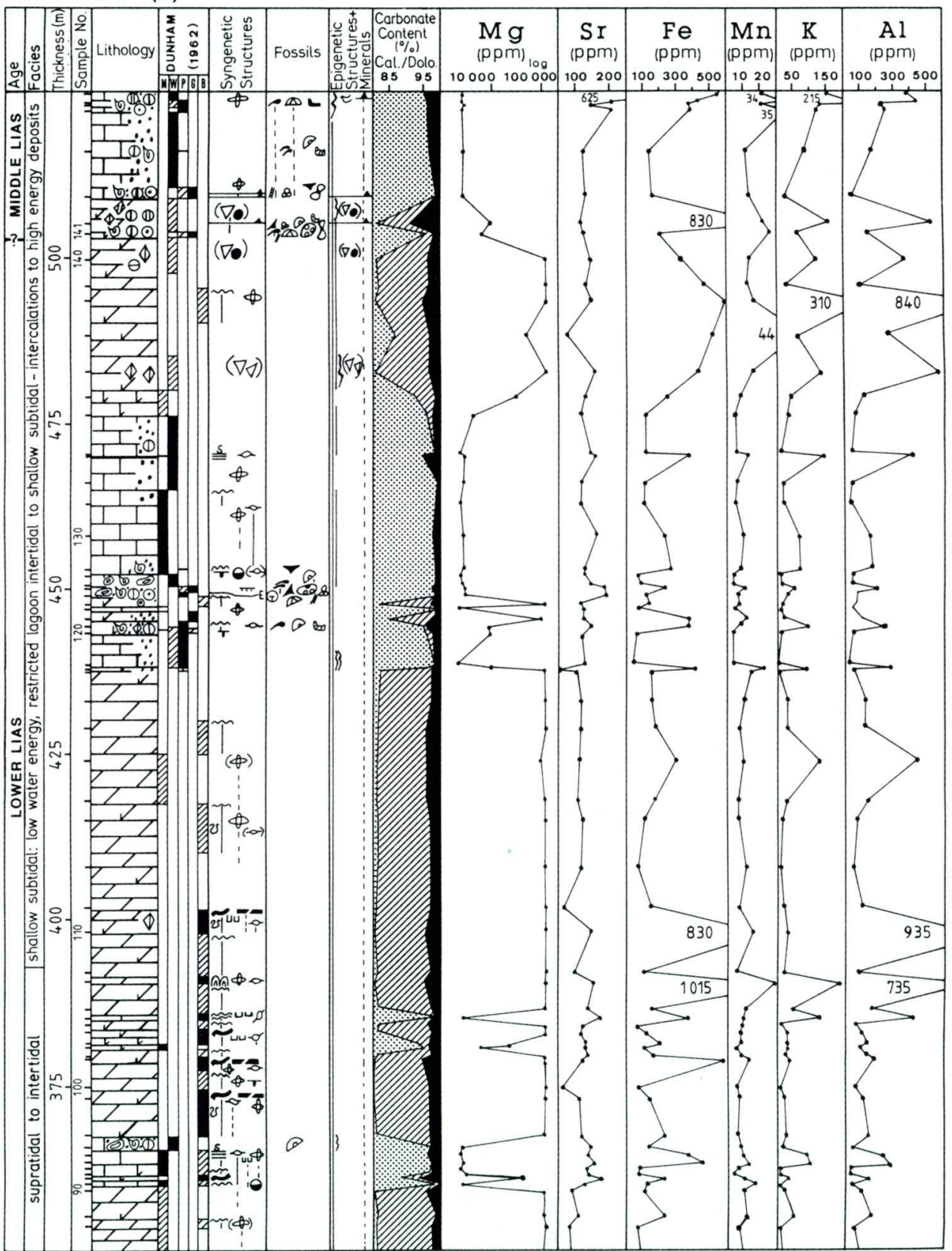


SECTION 2 (d)

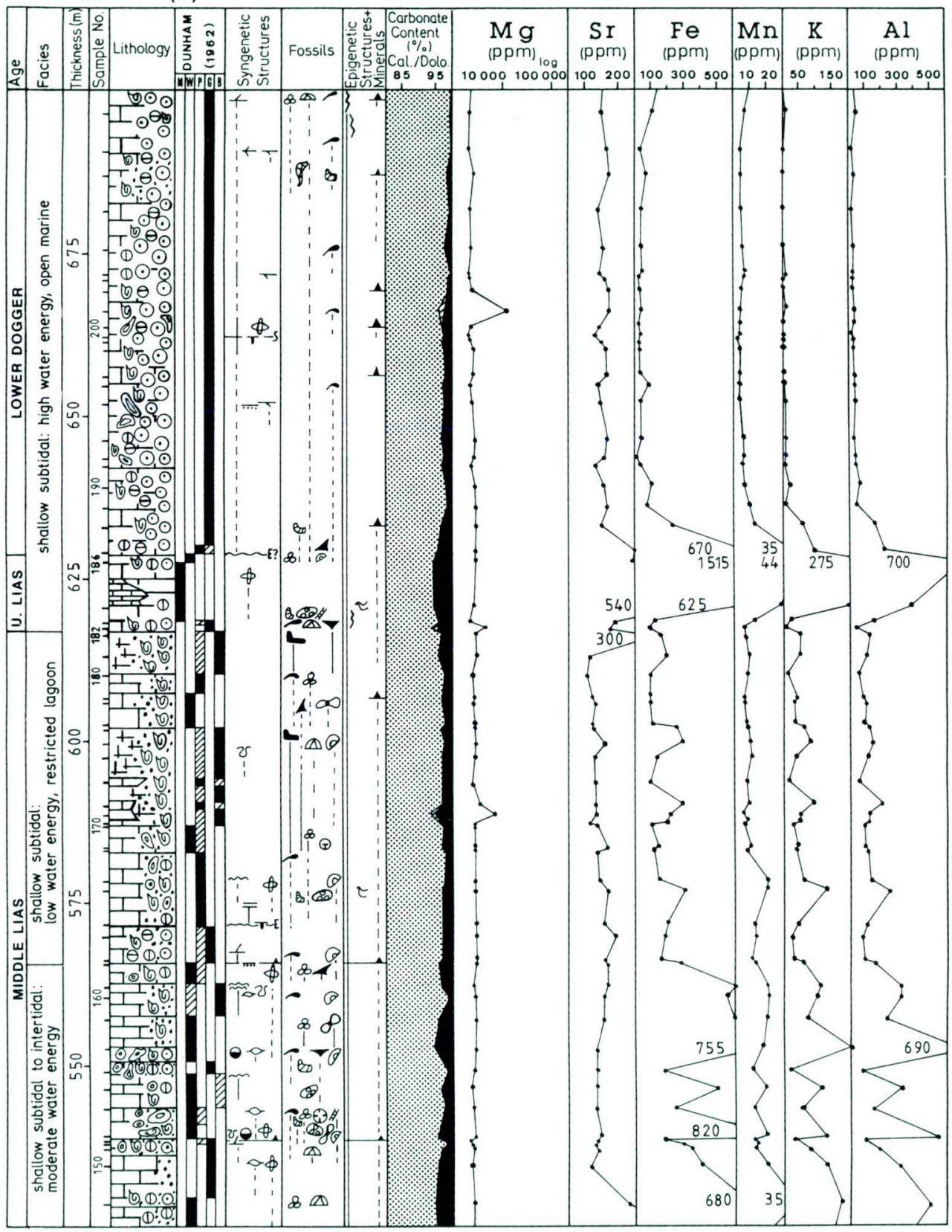


SECTION 2 (e)

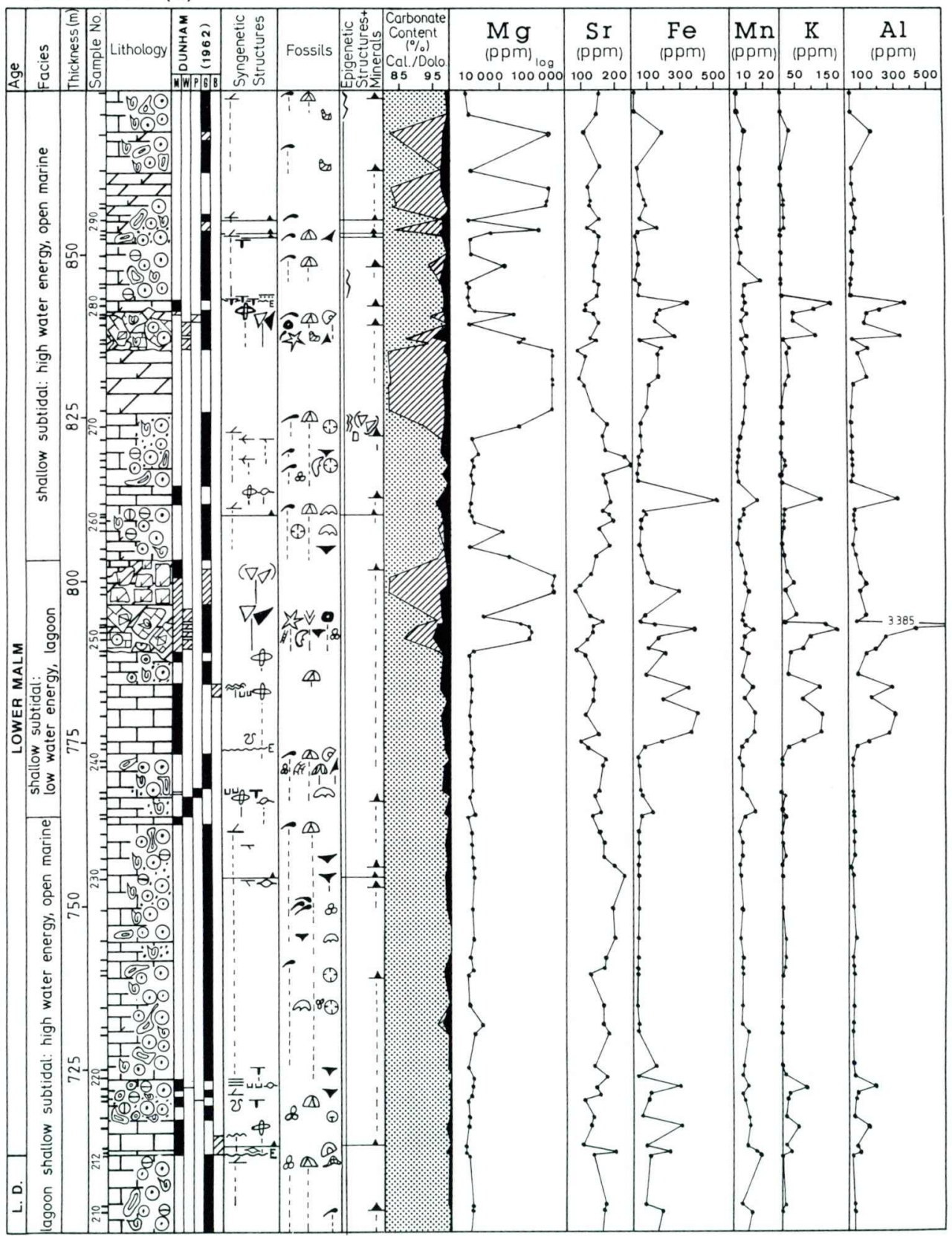


SECTION 2 (f)

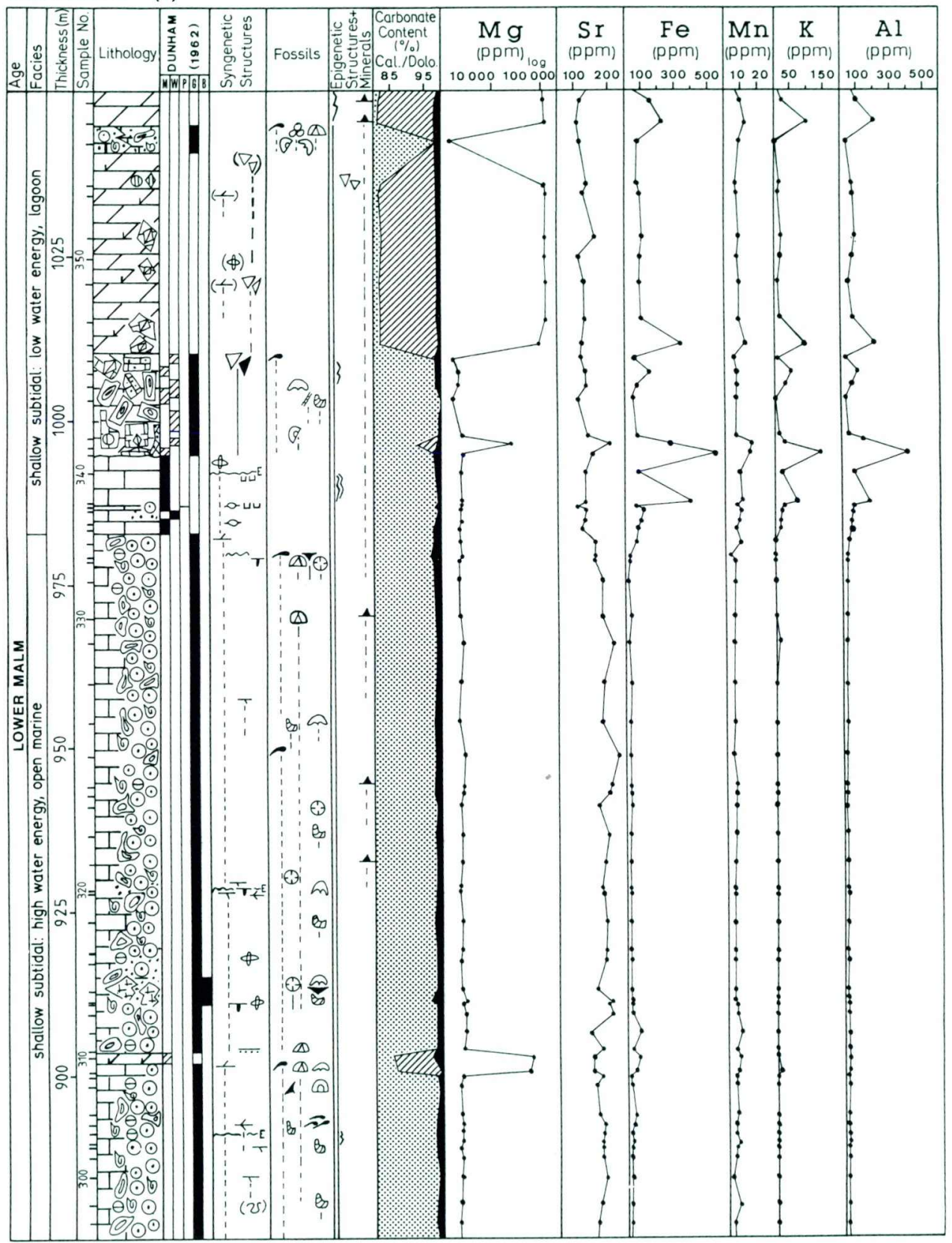


SECTION 2 (g)

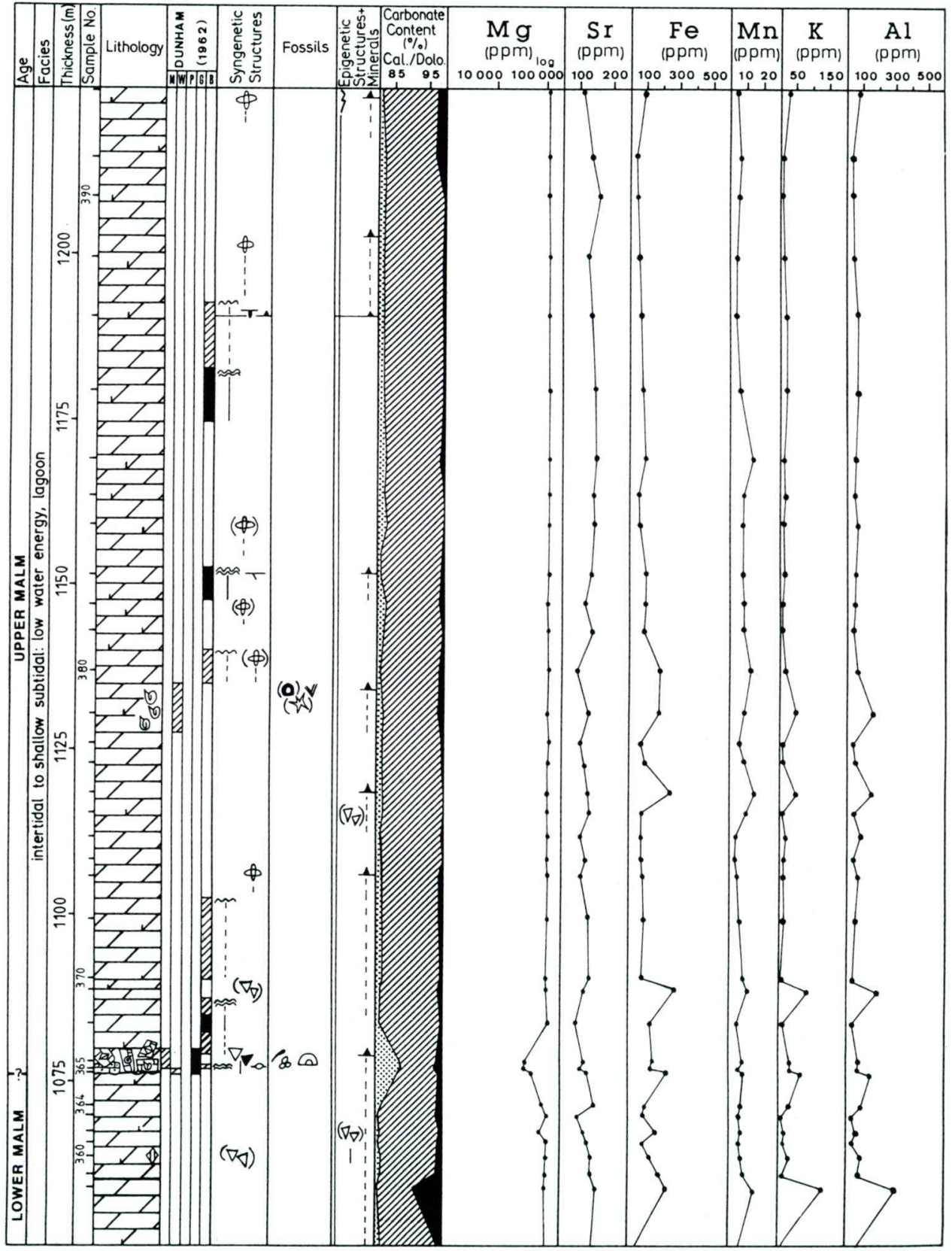


SECTION 2 (h, top)

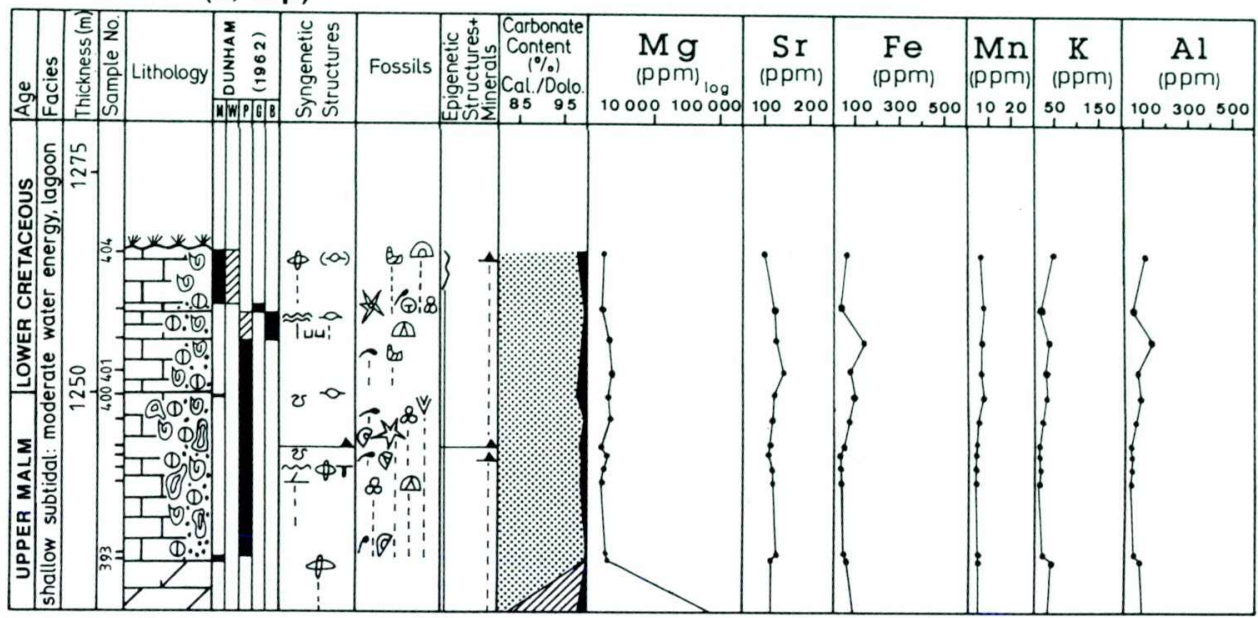

